
ability.

\title{
Americium Thermodynamic Data for the EQ3/6 Database
}

\author{
J. F. Kerrisk
}

\section{DISCLAIMER}

This report was prepared as an account of work sponsored by an agency of the United States Government. Neither the United States Government nor any agency thereof, nor any of their employees, makes any warranty, express or implied, or assurges any legal liability or responsibility for the acsuracy, completeness, or usefulness of any information, apparatus, product, or process disclosed, or represents that its use would not infringe privately owned rights. Reference herein to any specific commercial product, process, or service by trade name, tradenark, manufacturer, or otherwise does not necessarily constitute or imply its endorsement, recommendation, or favoring by the United States Government or any agency thereof. The views and opinions of authors expressed herein do not necessarily state or reflect those of the United States Government or any agency thereof.

\section{MASTER}

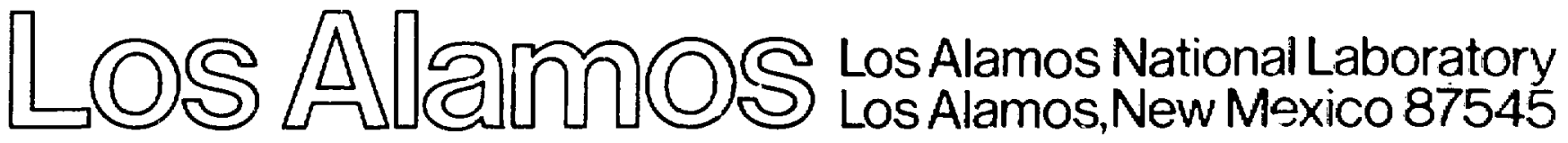


AMERICIUM THERMODYNAMIC DATA FOR THE EQ3/6 DATABASE

by

J. F. Kerrisk

\section{ABSTRACT}

Existing thermodynamic date for aqueous and solid species of americium have been reviewed and collected in a form that can be used with the EQ3/6 database. Data that are important in solubility calculations for americium at a proposed Yucca Mountain nuclear waste repository were emphasized. Conflicting data exist for americium complexes with carbonates. Essentially no data are available for americium solids or complexes at temperatures greater than $25^{\circ} \mathrm{C}$.

\section{INTRODUCTION}

Americium is one of the radioactive waste elements that exists in spent fuel and reprocessed waste from nuclear reactors. Two isotopes of americium, ${ }^{241} \mathrm{Am}$ and ${ }^{243} \mathrm{Am}$, are important radionuclides when considering geologic disposa] of radioactive wastes. 1 For this reason, an understanding of the solubility and speciation of americium in aqueous solution will be necessary for geochemical modeling of a repository. At Los Alamos, the EQ3/6 chemical equilibrium computer programs are being used for geochemical modeling of Yucca Mountain, the proposed site being studied as part of the Nevada Nuclear Waste Storage Investigations. 2 No thermodynamic data for americium are currently available in the EQ3/6 database, but the literature has been reviewed and data are being collected and added to the database. This americium database wil] be used to:

(1) assess the completeness and accuracy of existing thermodynamic data for americium,

(2) estimate the solubility of americium in water at Yucca Mountain, and 
(3) guide future experimental work to answer important questions about americium behavior in aqueous solution.

\section{TYPES OF THERMODYNAMIC DATA NEEDED}

The data needed for chemical equilibrium caiculatinns are equilibrium constants for reactions that involve the species of interest and the aqueous basis species. However, thermodynamic data are usually not compiled in this way. A program that is part of the EQ3/6 program package (MCRT) can be used to convert basic thermodynamic data, such as free ene, gies of formation, entropies, and heat capacities, into the data needed for equilibrium calculations. 3

A minimum requirement for aqueous species is the free energy of formation of the species from the elements in their standard states at one temperature. Data usually exist at $25^{\circ} \mathrm{C}$, and an equilibrium constarit can be calculated at that temperature by using the free energy of formation information. If, in addition, the entropy of the species or the entropy or enthalpy change of a reaction forming the species is known at the same temperature, a number of extrapolation techniques can be used to calculate equilibrium-constant data for the aqueous species over the 0 to $300^{\circ} \mathrm{C}$ temperatul 2 range.

For solids ti.., the minimum required data are the free energy of formation of the species frum the elements in their standard states at one temperature. This information can be used to calculate an equilibrium constant at that temperature. If heat capacity data or the enthalpy change for a reaction forming the species are also available, equilibrium constants can be determined at other temperatures.

\section{AMERICIUM DATA}

In the literature, there are thermodynamic data for 26 aqueous species of americium. In addition, three other aqueous species that could be important have been postulated, but no thermodynamic data have been reported at this time. A listing of the species and accompanying data are contained in App. A. which is a copy of the input file MDAQS for the MCRT program. The file contains a list of references for the data and explains how specific data were chosen when conflicting sources were available. Emphasis was given to complexes of $A m(I I I)$, which is the most likely oxidation state in dilute, 
near-neutral solutions. Data were found for complexes of $\mathrm{Am}^{3+}$ with $\mathrm{OH}^{-}, \mathrm{CC}_{3}^{2-}$, $\mathrm{F}^{-}, \mathrm{Cl}^{-}, \mathrm{SO}_{4}^{2-}, \mathrm{PO}_{4}^{3-}$, and $\mathrm{NO}_{3}^{-}$. At least one species in three other oxidation states $\left(\mathrm{Am}^{4+}, \mathrm{AmO}_{2}^{+}\right.$, and $\left.\mathrm{AmO}_{2}^{2+}\right)$ was also included.

Thermodynamic data were found for only three solids of americium that would likely precipitate from aqueous solution: $\mathrm{Am}(\mathrm{OH})_{3}, \mathrm{Am}(\mathrm{OH}) \mathrm{CO}_{3}$, and $\mathrm{Am}_{2}\left(\mathrm{CO}_{3}\right)_{3}$. Solubility measurements have also been reported for solid $\mathrm{AmO}_{2}$, but the authors did not report equilibrium-constant data. A listing of the species and accompanying data are contained in App. B, which is a copy of the input file MDSOL for the MCRT program. The file contains a list of references for the data and explains how specific data were chosen when conflicting sources were available.

Appendix $C$ contains a listing of the input file REAC for the MCRT program. REAC specifies the reactions involving the americium complexes and solids for which equilibrium constants will be determined by the MCRT program.

The output from the MCRT program is a file containing equilibrium-constant data for the reactions specified at $0,25,60,100,150,200,250$, and $300^{\circ} \mathrm{C}$. Appendix $D$ contains a listing of this file, which also gives data for the species, the reaction being considered, and equilibrium constants as $\log _{10} \mathrm{~K}$. A value of 500 for $\log _{10} \mathrm{~K}$ indicates that no data are available at that temperature.

\section{DISCUSSION}

The americium data collected in this review have been examined in an attempt to discover any discrepancies or inconsistencies. This is particularly important when data from more than one source are available or when the choice of other thermodynamic data influences the results of a particular experimenter.

Data for three of the hydrolysis products of $\mathrm{Am}^{3+}\left[\mathrm{Am}(\mathrm{OH})^{2+}, \mathrm{Am}(\mathrm{OH})_{2}^{+}\right.$, and $\left.\mathrm{Am}(\mathrm{OH})_{3}\right]$ have been reported by a number of experimenters (see App. A references). A fourth hydrolys is product $\left[\mathrm{Am}(\mathrm{OH})_{4}^{-}\right]$has been postulated by analogy with the rare earths, but no evidence for its existence has been published. 4 Figure 1 shows a plot of $\log _{10} k$ for the reaction

$$
\mathrm{Am}^{3+}+\mathrm{nOH}^{-}=\mathrm{Am}(\mathrm{OH})_{n}^{(3-n)} \text {, }
$$




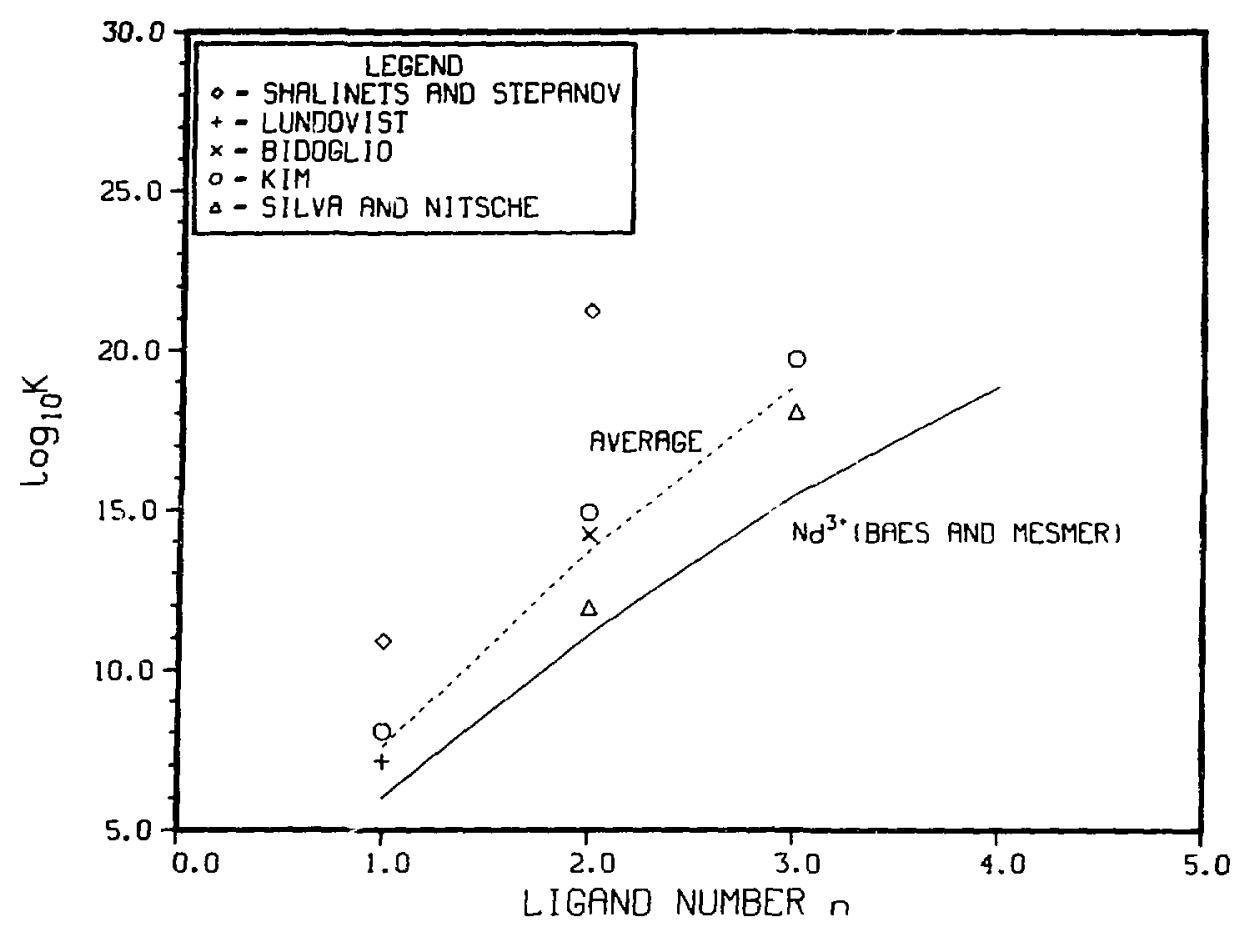

Fig. 1. Americium hydrolys is products.

as a function of the number of ligands $n .^{5-9}$ Three values have teen shown for $n=1$, four values for $n=2$, and two values for $n=3$. In addition, data for the analogous reaction for neodymium are shown. ${ }^{10}$ The $\mathrm{Nd}^{3+}$ ion is often used as a chemical analogue for $\mathrm{Am}^{3+}$. The americium complexes appear to be more stable $\left(\right.$ larger $\left.\log _{10} K\right)$ than the comparable neodymium complexes. There was no clear reason to select the data of any one or two experimenters for these complexes; instead, average values were chosen and are shown by the dashed line in Fig. 1 (see comments in App. A for these species). In determining these average values, Shalinets and Stepanov's data for $n=1$ and $n=2$ were disregarded as being out of line with the other reported data. ${ }^{5}$

There have been two recent reports of the solubility of solid $\mathrm{Am}(\mathrm{OH})_{3} \cdot{ }^{8,11}$ Calculating a solubility product for $\mathrm{Am}(\mathrm{OH})_{3}$ requires knowledge of the hydrolysis equilibria; values for formation constants of hydrolysis products must either be assumed or determined as part of the work. Thus, the resulting solubility product is related to the choice of hydrolysis equilibrium constants; if either the solubility product or hydrolysis equilibrium constants are varied independently, incorrect predictions of solubility can result. Thermodynamic 
data for solid $\mathrm{Am}(\mathrm{OH})_{3}$ were chosen as intermediate between the values reported by Silva ${ }^{11}$ and $\mathrm{Kim}^{8}$ and were consistent with the choices of hydrolysis-product equilibrium constants described in the previous paragraph. Figure 2 shows the calculated solubility of solid $\mathrm{Am}(\mathrm{OH})_{3}$ compared with measured solubilities under the conditions of the two experimental measurements. Repr ted solubilities of americium from Edelstein ${ }^{12}$ and Rai $^{13}$ are also showi; the identity of the solid phase controlling solubility was not determined in either of these experiments.

The solubility of solid $\mathrm{AmO}_{2}$ was also reported as a function of $\mathrm{pH}$ by Kim. ${ }^{8}$ Dissolution of $\mathrm{AmO}_{2}$ involves the reduction of $\left.\mathrm{Am}^{4+} \mathrm{t}\right) \mathrm{Am}^{3+}$ and the formation of $\mathrm{Am}^{3+}$ complexes in solution. Tnus, the solution Eh or some other measure of the redox state of the solution is necessary to interpret the solubility data in terms of equilibrium reactions. This work did not include redox measurements, so meaningful thermodynamic data cannot be derived from the solubility data.

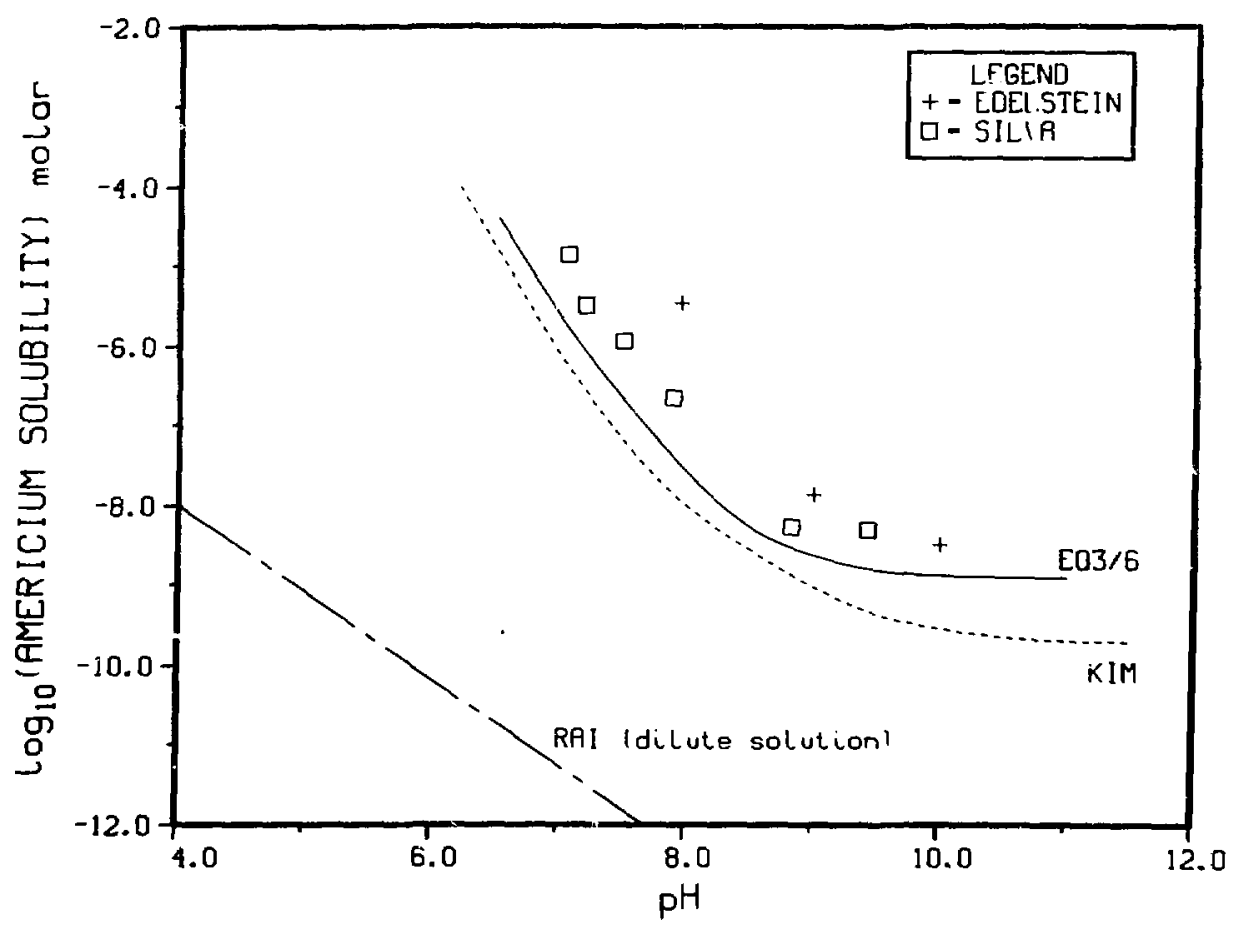

Fig. 2. Americium solubility in $0.1 \mathrm{M} \mathrm{NaClO}_{4}$ at $25^{\circ} \mathrm{C}$. 
Bidoglio ${ }^{6}$ and Lundqvist ${ }^{7}$ have experimentally determined complex formation between $\mathrm{Am}^{3+}, \mathrm{OH}^{-}$, and carbonate species. This work has recently been reviewed by Newton and Sullivan. ${ }^{14}$ The species identified in each work and their formation constants were used with the hydrolys is products of $\mathrm{Am}^{3+}$ (defined above) tn calculate the predominant species in aqueous solution in the $\mathrm{pH}$ range from 6 to 11 . Figure 3 shows the results for total carbonate of $2 \times 10^{-3} \mathrm{M}$ at ionic strength 0.1 . These conditions are similar to the experimental conditions employed by the two investigators. It is apparent that the predominant species predicted from the two sets of formation constants are quite different. Bidoglio should have seen evidence for the $\mathrm{AmCO}_{3}^{+}$complex reported by Lundqvist, and Lundqvist should have observed the $\mathrm{AmHCO}_{3}^{2+}$ and $\mathrm{Am}\left(\mathrm{HCO}_{3}\right)_{2}^{+}$ complexes reported by Bidoglio. In the range of interest for water at yucca

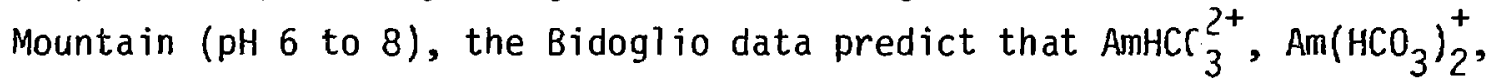
and $\mathrm{Am}\left(\mathrm{CO}_{3}\right)_{2}^{-}$are the primary aqueous species, whereas the Lundqvist data predict that $\mathrm{Am}^{3+}, \mathrm{AmCO}_{3}^{+}, \mathrm{Am}\left(\mathrm{CO}_{3}\right)_{2}^{-}$, and two of the hydrolys is products $\left(\mathrm{AmOH}^{2+}\right.$ and $\left.\mathrm{Am}(\mathrm{OH})_{2}^{+}\right)$predominate. At this time, there are no other sources of information that would verify either of these two conflicting sets of data. The Lundqvist data have been employed for further calculations with EQ3/6 (see App. A), but this should be considered as an interim choice that will probably be modified as more data become available.

Evidence has been reported for two solids of americium with carbonate, $\mathrm{Am}(\mathrm{OH}) \mathrm{CO}_{3}$ and $\mathrm{Am}_{2}\left(\mathrm{CO}_{3}\right)_{3}$. Silva and $\mathrm{Nitsche}{ }^{9}$ have recently reported a formation constant for solid $\mathrm{Am} \mathrm{OH}) \mathrm{CO}_{3}$; they employed the complex formation constants of Lundqvist to analyze their data so their result was used directly. Their experiment was conducted at $\mathrm{pH} 6.1$ and total carbonate of $2 \times 10^{-4} \mathrm{M}$; neitiver of the carbonate complexes reported by Lundqvist is important under these conditions. If the carbonate complexes reported by Bidoglio had been used to analyze the data, significant aqueous concentrations of $\mathrm{AmHCO}_{3}^{2+}$ and $\mathrm{Am}\left(\mathrm{HCO}_{3}\right)_{2}^{+}$ would exist under these conditions and the reported formation constant would be different. Shiloh et al. ${ }^{15}$ reported zvidence for the formation of solid $\mathrm{Am}_{2}\left(\mathrm{CO}_{3}\right)_{3}$ at high carbonate concentrations and high $\mathrm{pH}$. The reported solubility of this material was used to estimate a solubility product for the solid. This estimate should be considered speculative it this time. 
PERCENT OF ROLEOUS SPECIES FRESENT

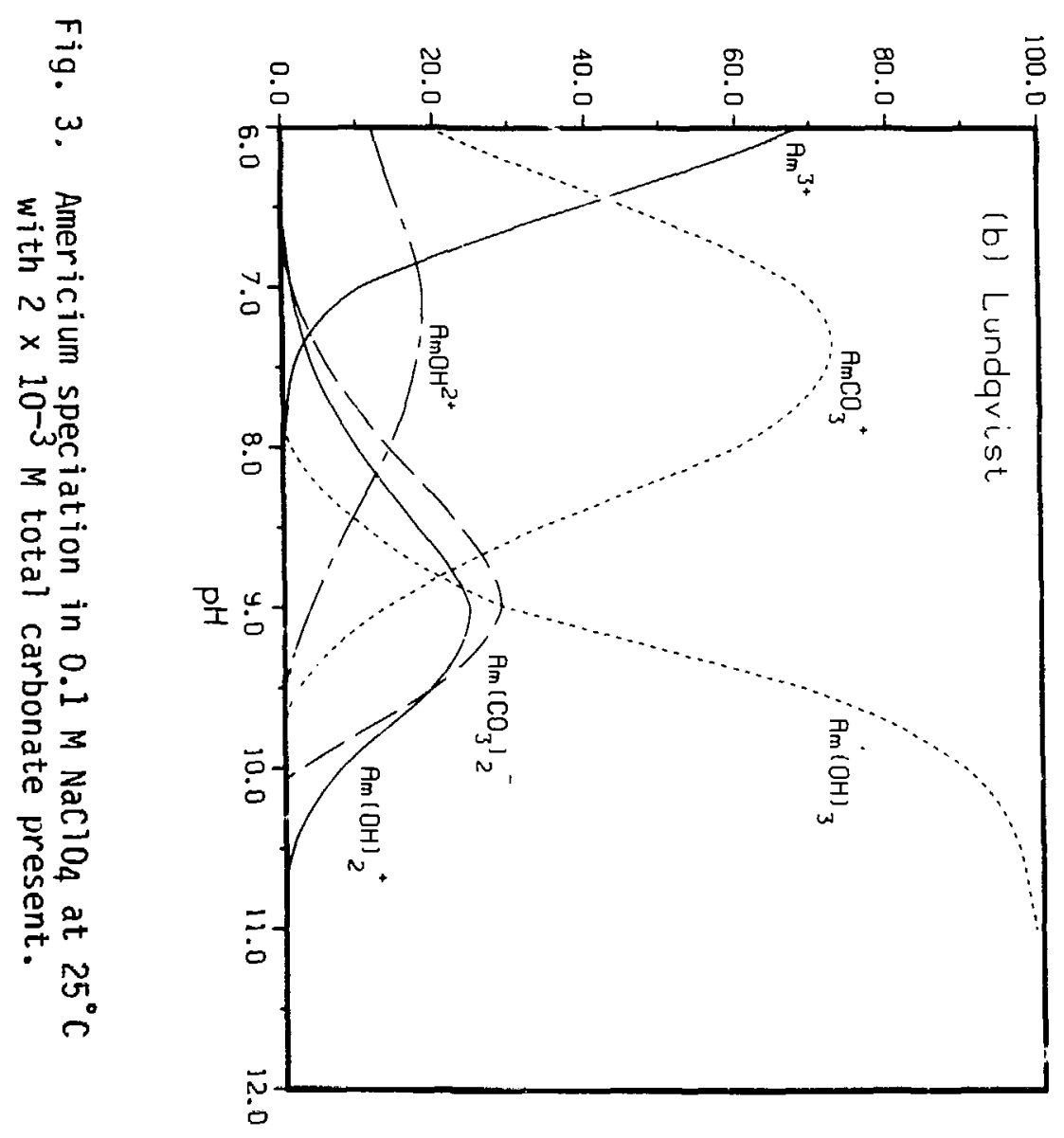

PERCENT OF AOUEOUS SPECIES PRESENT

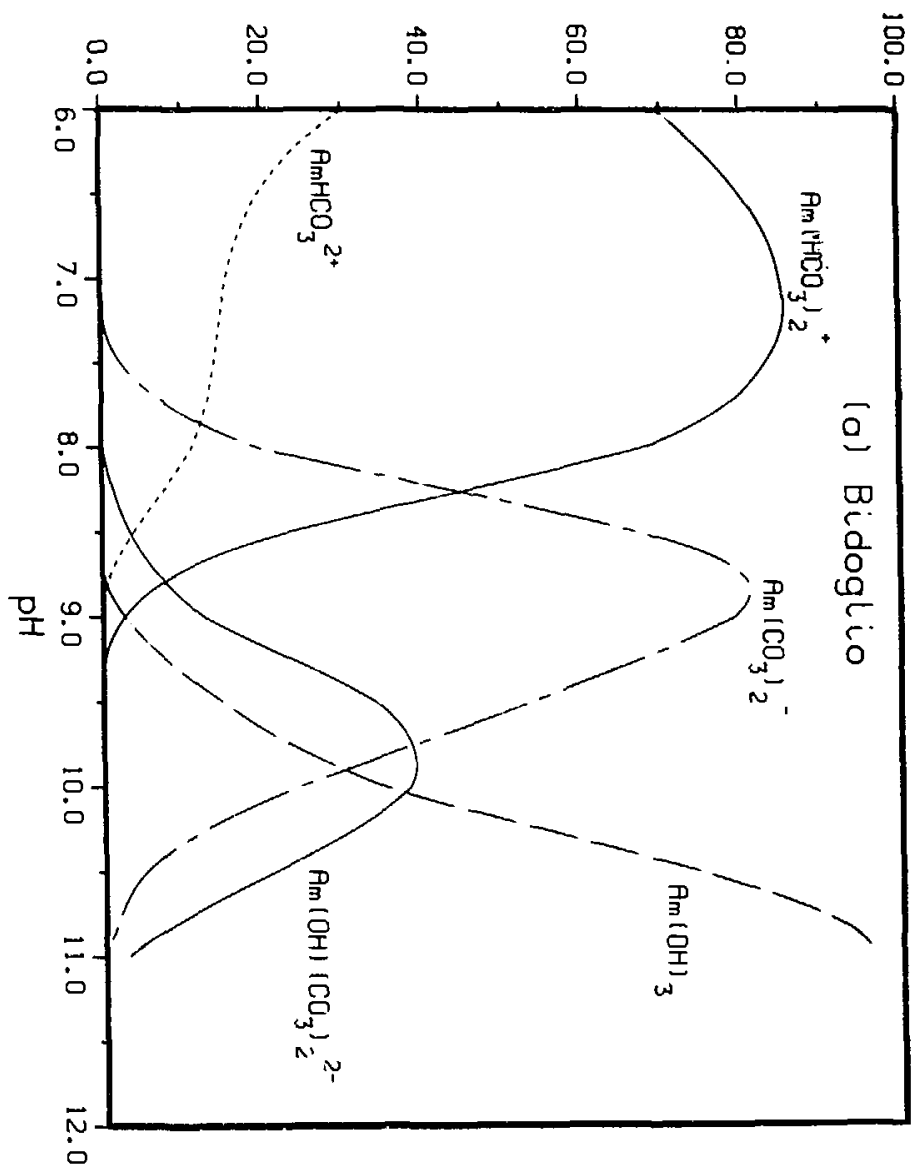


Data for the formation of americium complexes with $\mathrm{F}^{-}, \mathrm{Cl}^{-}, \mathrm{SO}_{4}^{2-}, \mathrm{PO}_{4}^{3-}$, and $\mathrm{NO}_{3}^{-}$are also listed in App. A. Where possible, thermodynamic data for these complexes were taken from the review by Phillips. 16 of these anions, only complexes with $\mathrm{F}^{-}$appear to be of any importance in water at Yucca Mountain (see the following section). Formation constants for the fluoride complexes were taken from Phillips' review; they appear to be reliable data.

One aspect of essentially all the data collected for americium is that only $25^{\circ} \mathrm{C}$ data are available. For a thorough analys is of americium solubility, it may be necessary to extend data for important complexes and solids to higher temperatures.

\section{SOLUBILITY OF AMERICIUM IN WATER FROM YUCCA MOUNTAIN}

The solubility of americium will influence its rate of transport from a repository along water flowpaths toward the accessible environment. Calculations of americium solubility in water from Yucca Mountain were done using EQ3/6 and the thermodynamic data 1 isted in App. D. Analyses of water from Wel1 J-13 at the Nevada Test Site were used to define the water composition. 17 The observed $\mathrm{pH}$ of Well J-13 water is approximately 7 , and total carbonate is $2.3 \times 10^{-3} \mathrm{M}$. The Eh was assumed to be $400 \mathrm{mV}$; this assumption shouid not affect the results because only the Am(III) oxidation state is expected in dilute, near-neutral solutions. It was assumed that the solid controlling solubility is $\mathrm{Am}(\mathrm{OH}) \mathrm{CO}_{3}$. Figure 4 shows a plot of americium solubility and the predominant aqueous americium species from $\mathrm{pH} 6$ to 8 . At $\mathrm{pH} 6$, a variety of species contribute to the aqueous americium content; at $\mathrm{pH} 7$ to $8, \mathrm{AmCO}_{3}^{+}$ is the predominant aqueous species. With Well J-13 water in this pH range, the hydrolysis products are not important aqueous species. Solid $\mathrm{Am}_{2}\left(\mathrm{CO}_{3}\right)_{3}$ was also near saturation under these conditions. Although solid $\mathrm{Am}(\mathrm{OH})_{3}$ was undersaturated, it could control solubility at higher $\mathrm{pH}$ or at lower total carbonate.

\section{RECOMMENDATIONS}

This review has highlighted two problems with the available thermodynamic daia that will be used to calculate americium solubility in aqueous solutions such as Well J-13 water. There is a conflict between the only two available sources of data for americium complexes with carbonate species. Because carbonate is the primary anion in water from Yucca Mountain, this conflict 

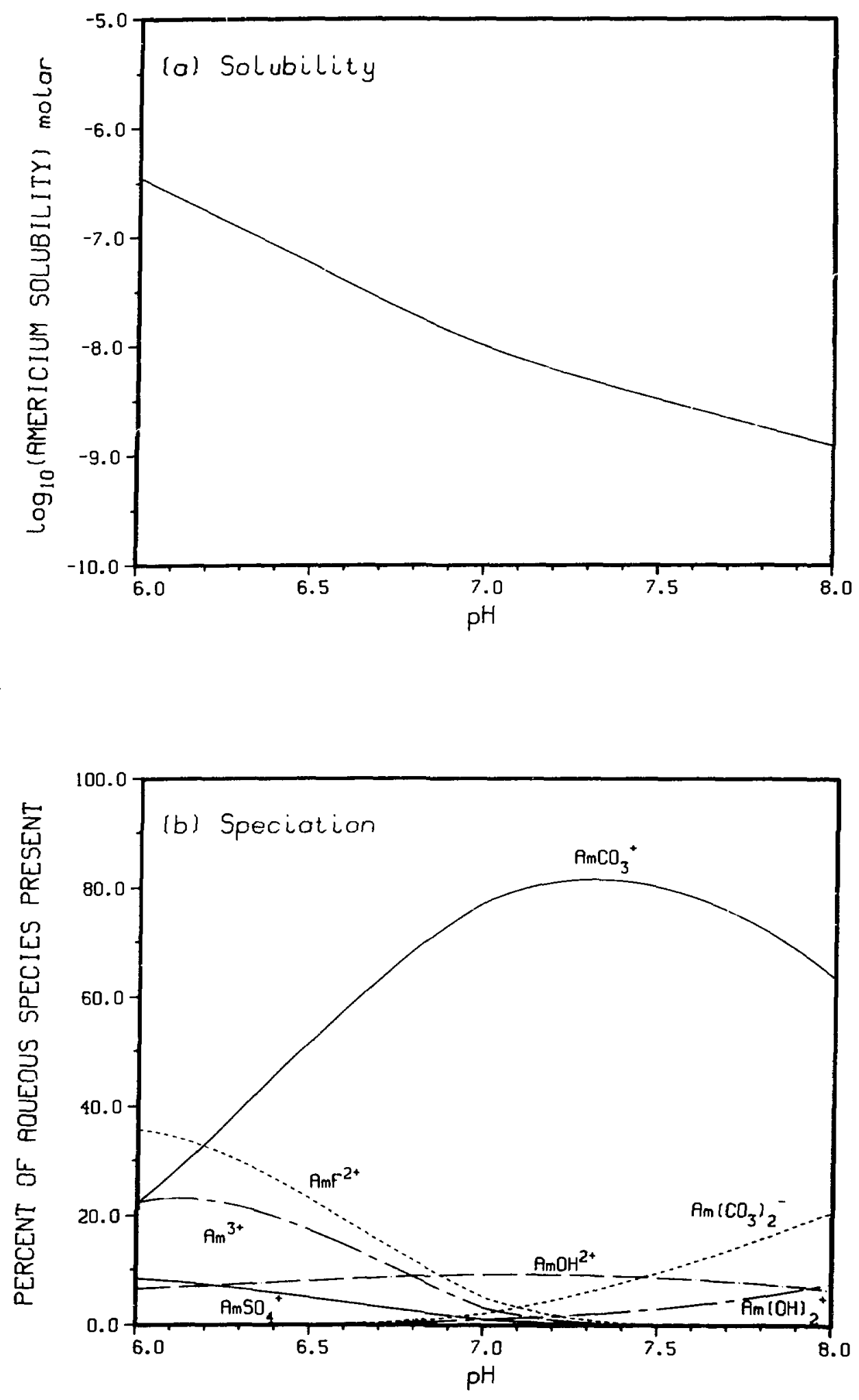

Fig. 4. Americium solubility and speciation in well $\mathrm{J}-13$ water at $25^{\circ} \mathrm{C}$. 
must be resolved before americium solubility and speciation can be accurately determined for performance assessment. Further experimental work is needed to (a) identify the stoichiometry of the predorninant aqueous complexes of americium with carbonate and (b) determine their formation constants. The second problem is that only data at $25^{\circ} \mathrm{C}$ are available for most americium species and compounds. Higher temperature data are needed, especially for solids controlling solubility and predominant aqueous species.

\section{REFERENCES}

1. Environmental Protection Agency, "Environmental Standards for the Management and Disposal of Spent Nuclear Fuel, High-Leyel, and Transuranic Radicactive Wastes," Federal Register 47, No. 250, December 29, 1982, pp. 58196-58206.

2. T. J. Wolery, "Calculation of Chemical Equilibrium between Aqueous Solution and Minerals: The EQ3/6 Software Package," Lawrence Livermore Laboratory report UCRL-52658 (February 1979).

3. T. J. Wolery, "MCRT, A Data Base Building Code for the E03/6 Geochemical Modeling Software Package," Lawrence Livermore National Laboratory report (in preparation).

4. B. Allard, "Solubilities of Actinides in Neutral or Basic Solutions," in Actinides in Perspective, N. M. Edelstein, Ed. (Pergamon Press, iew York, 1982).

5. A. Shalinets and A. Stepanov, "Investigation of Complex Formation of the Trivalent Actinide and Lanthanide Elements by the Method of Electromigration. XVII. Hydrolysis," Radiokhimiya (English Trans.) 14, 290-293 (1972).

6. G. Bidoglio, A. De Plano, and A. Chatt, "Studies on Speciation of Americium, Technecium, and Neptunium in Simulated Vitrified-Waste Leachates," in Brookins, G., Ed., Scientific Basis for Nuclear Waste Management VI (North Holland, New York, 1983).

7. R. Lundqvist, "Hydrophilic Complexes of the Actinides. I, Carbonates of Trivalent Americium and Europium," ACTA Chemica Scand. A. 36, 741-750 (1982).

8. J. Kim, M. Bernkopf, Ch. Lierse, and F. Koppold, "Hydroiysis Reactions of $A m(I I I)$ and $P u(V I)$ in Near Neutral Solutions," Presented at the 185th Meeting of the American Chemical Society, Seattle, Washingtor, March 20-25, 1983, paper no. 91. 
9. R. Silva and H. Nitsche, "Thermodynamic Properties of Chemical Species of Waste Radionuclides," in "NRC Nuclear Waste Geochemistry 83," D. H. Alexander and G. F. Birchard, Eds., US Nuclear Regulatory Commission report NUREG/CP-0052 (May 1984).

10. C. F. Baes, Jr., and R. E. Mesmer, The Hydrolys is of Cations (John Wiley and Sons, New York, 1976), pp. 129-146.

11. R. Silva, "The Solubilities of Crystailine Neodymium and Americium Trihydroxides," Lawrence Berkeley Laboratory report LBL-15055 (1982).

12. N. Edelstein, J. Bucher, R. Silva, and H. Nitsche, "Thermodynamic Properties of Chemical Species in Nuclear Waste," Lawrence Berkeley Laboratory report LBL-14325 (January 1983).

13. D. Rai, R. G. Strickert, D. A. Moore, and R. J. Serne, "Influence of an Americium Solid Phase on Americium Concentrations in Solution, "Geochim. Cosmochim. Acta 45, 2257-2265 (1981).

14. T. W. Newton and J. C. Sullivan, "Actinide Carbonate Complexes in Aqueous Solution," in Handbook on Actinides (to be published by North-Holland Publishing Co.T.

15. M. Shiloh, M. Givon, and Y. Marcus, "A Spectrophotometric Study of the Trivalent Actinide Complexes in Solution - III. Americium with Bromide, Iodide, Nitrate and Carbonate Ligands," Inorg. Nucl. Chem. 31, 1807-1814 (1969).

16. S. L. Phillips, "Hydrolysis and Formation Constants at $25^{\circ} \mathrm{C}$ " Lawrence Berkeley Laboratory report LBL-14313 (May 1982).

17. W. R. Daniels, K. Wolfsberg, R. S. Rundberg, A. E. Ogard, J. F. Kerrisk, C. J. Duffy, et al., "Summary Report on the Geochemistry of Yucca Mountain and Environs," Los Alamos National Laboratory report LA-9328-MS (December 1982). 


\section{APPENDIX A}

Appendix $A$ is a listing of the input file MDAQS for the MCRT program. This file contains thermodynamic data for aqueous species of americium. 


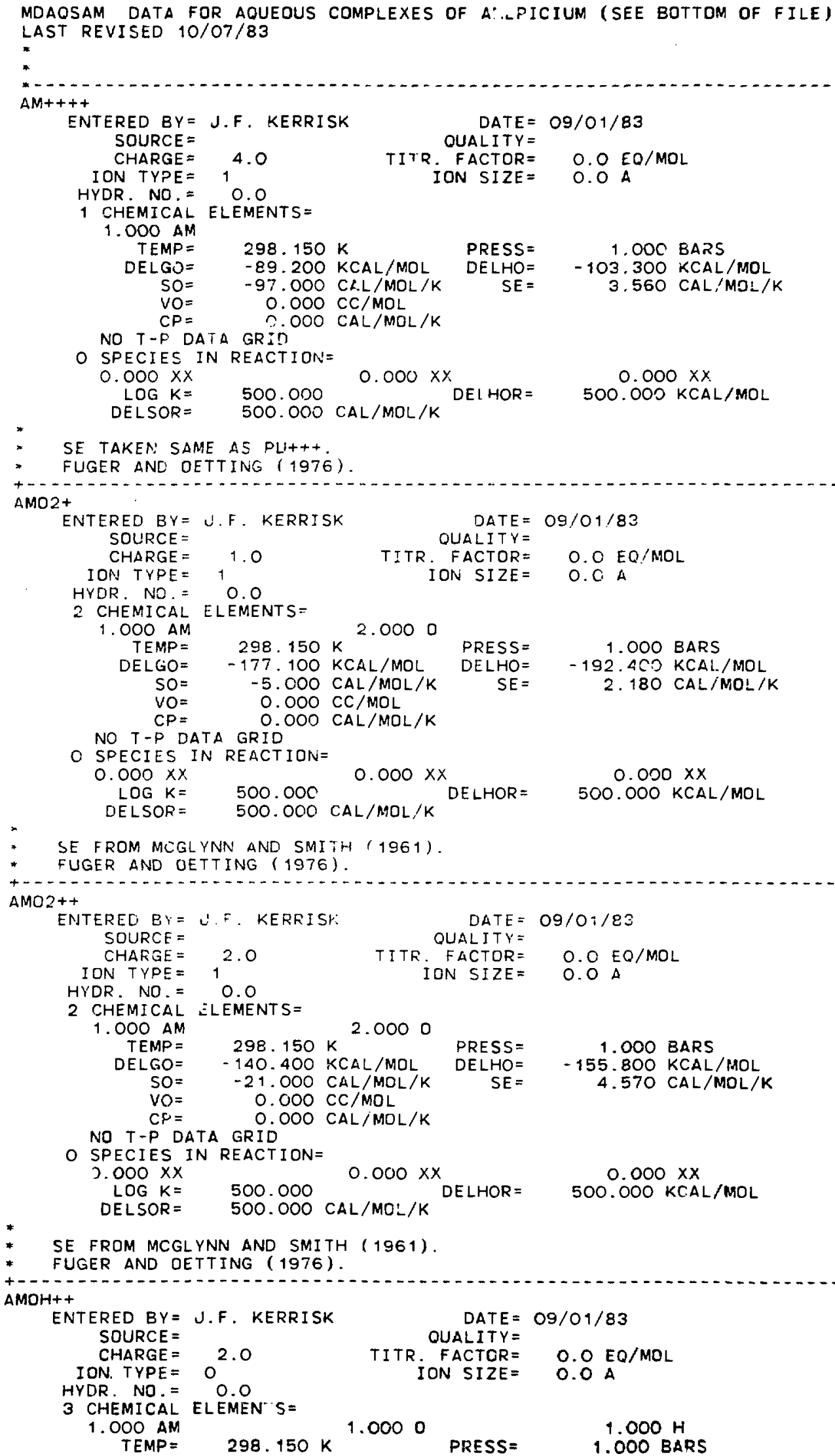

0.0 EQ/MOL

O.C A

\footnotetext{
- SE FROM MCGLYNN AND SMITH (1961).
} OUALITY = TITR. FACTOR= ION $S I Z E=$$$
0.0 \mathrm{EQ} / \mathrm{MOL}
$$

$0.0 \mathrm{~A}$

$0.000 x x$ $500.000 \mathrm{KCAL} / \mathrm{MOL}$

SPECIES IN REACTION=

2. $000 \times X$

LOG $K=$

DELSOR =

500.000

$0.000 \times X$

500.000 CAL/MOL/K DE LHOR =

$0.000 \times X$

1.00O BARS

$-155.800 \mathrm{KCAL} / \mathrm{MOL}$

$4.570 \mathrm{CAL} / \mathrm{MOL} / \mathrm{K}$

SE FROM MCGLYNN AND SMITH (1961)

FUGER AND OETTING (1976).

\section{$\mathrm{AMOH}+$}

ENTERED BY = U.F. KERRISK

SOURCE =

CHARGE =

ION. TYPE $=$

HYDR. NO. =

$\mathrm{O}^{2.0}$

3 CHEMICAL ELEMEN ${ }^{-5} \mathrm{~S}=$

1. 000 AM

TEMP =

$298.150 \mathrm{~K}$

1.0000

TITR OUALTY ION SIZE =

$0.0 \mathrm{EQ} / \mathrm{MOL}$
$0.0 \mathrm{~A}$

$500.000 \mathrm{KC} . A L / M O L$ 


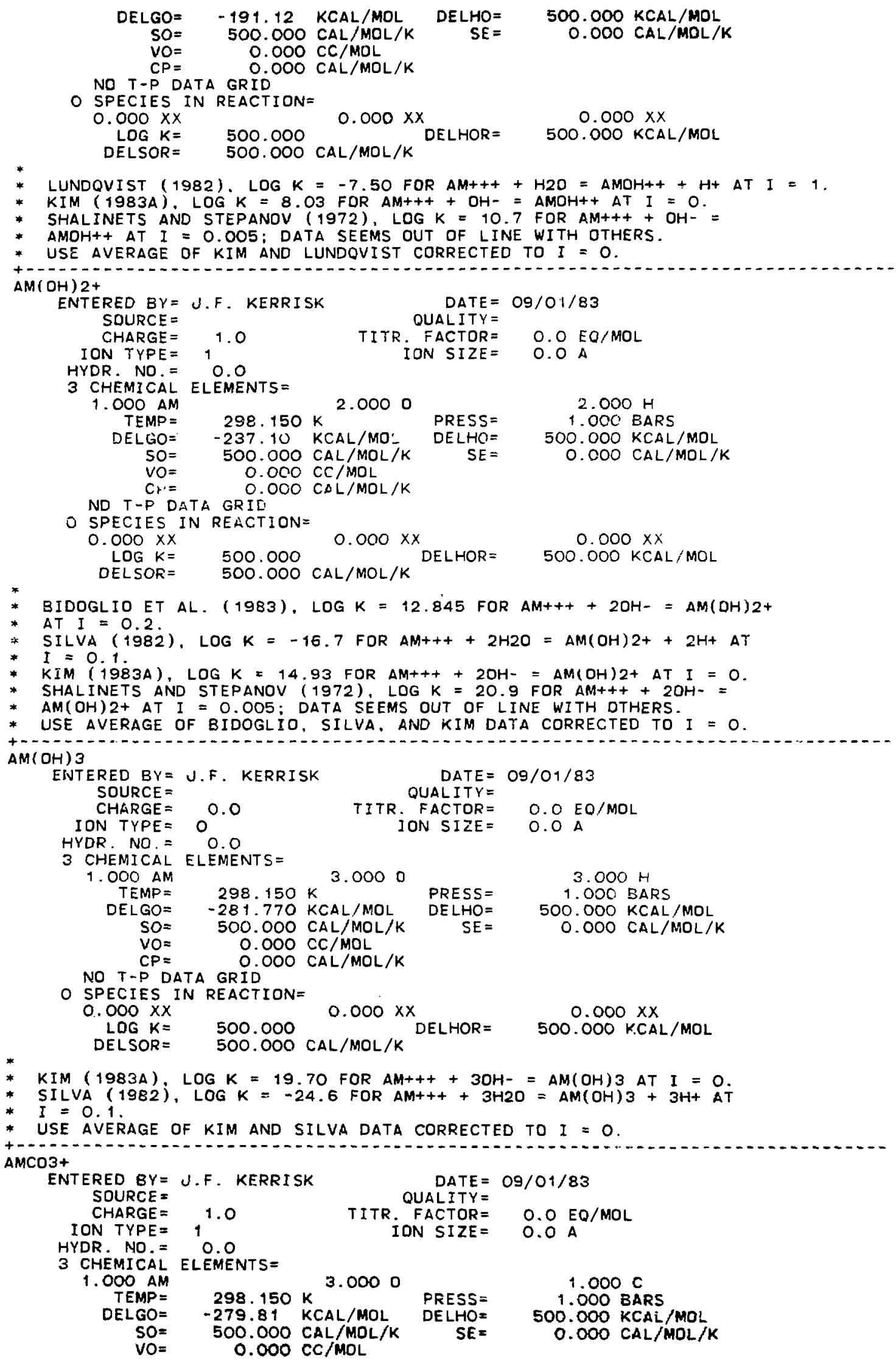




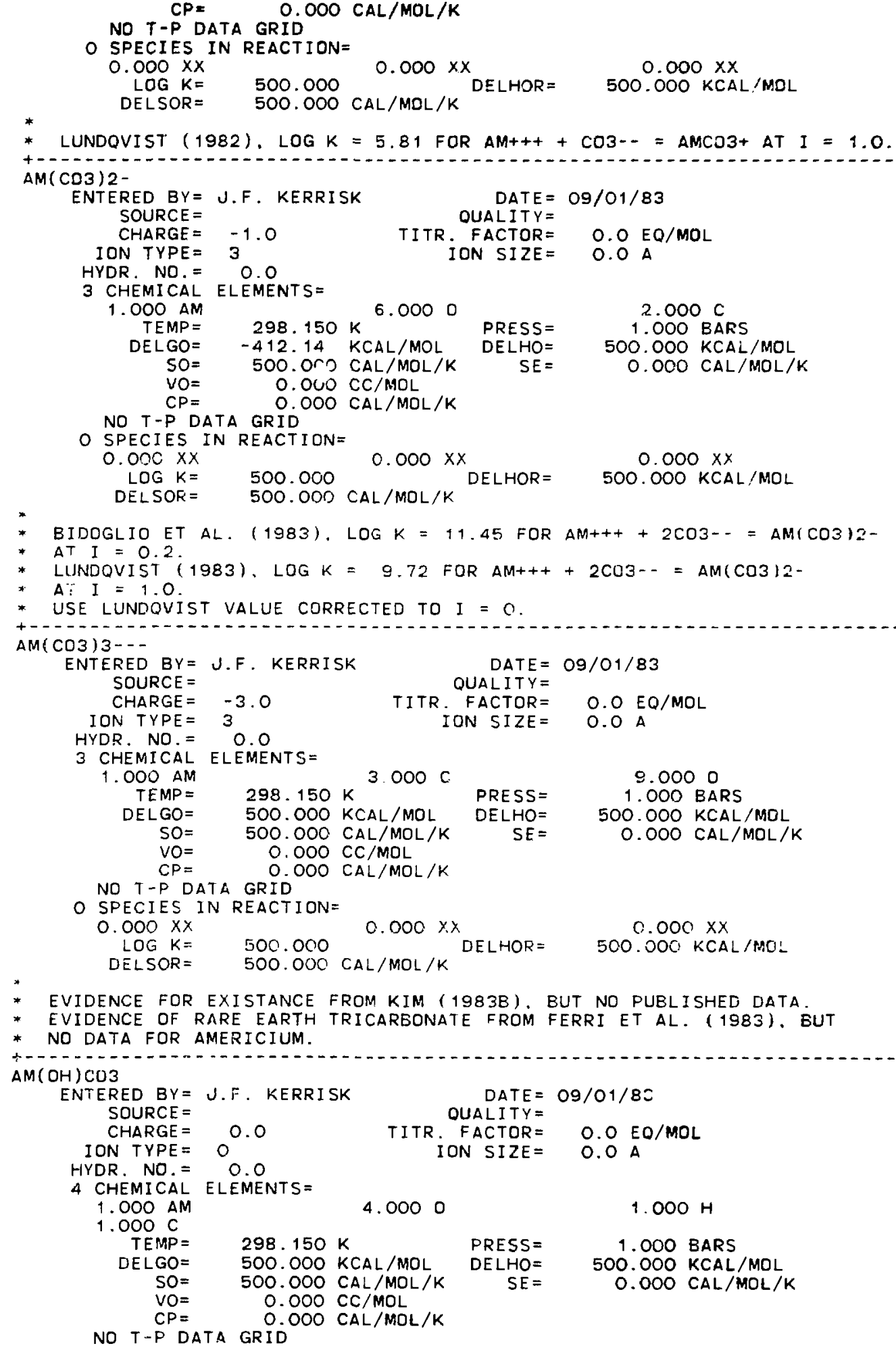




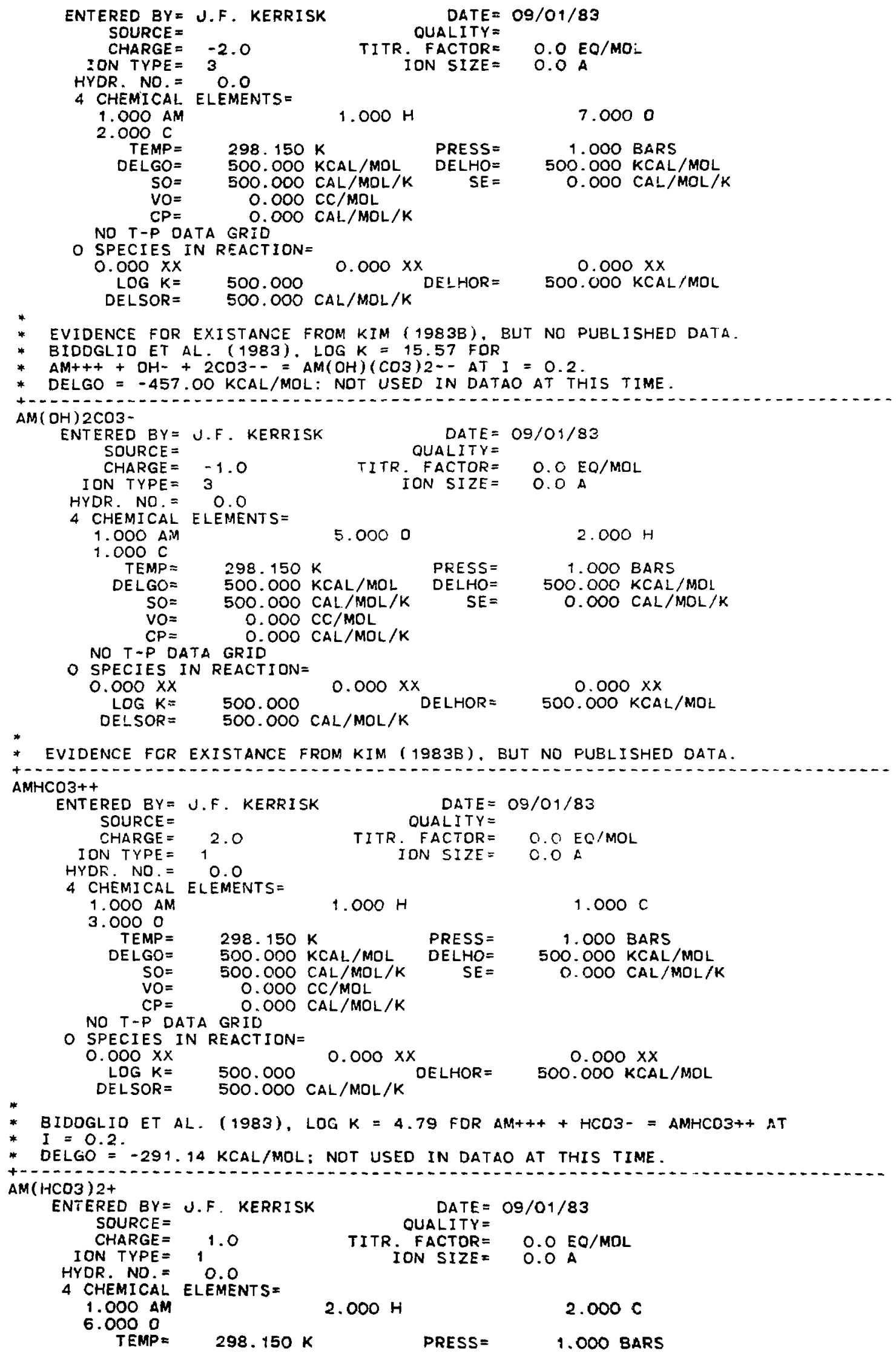




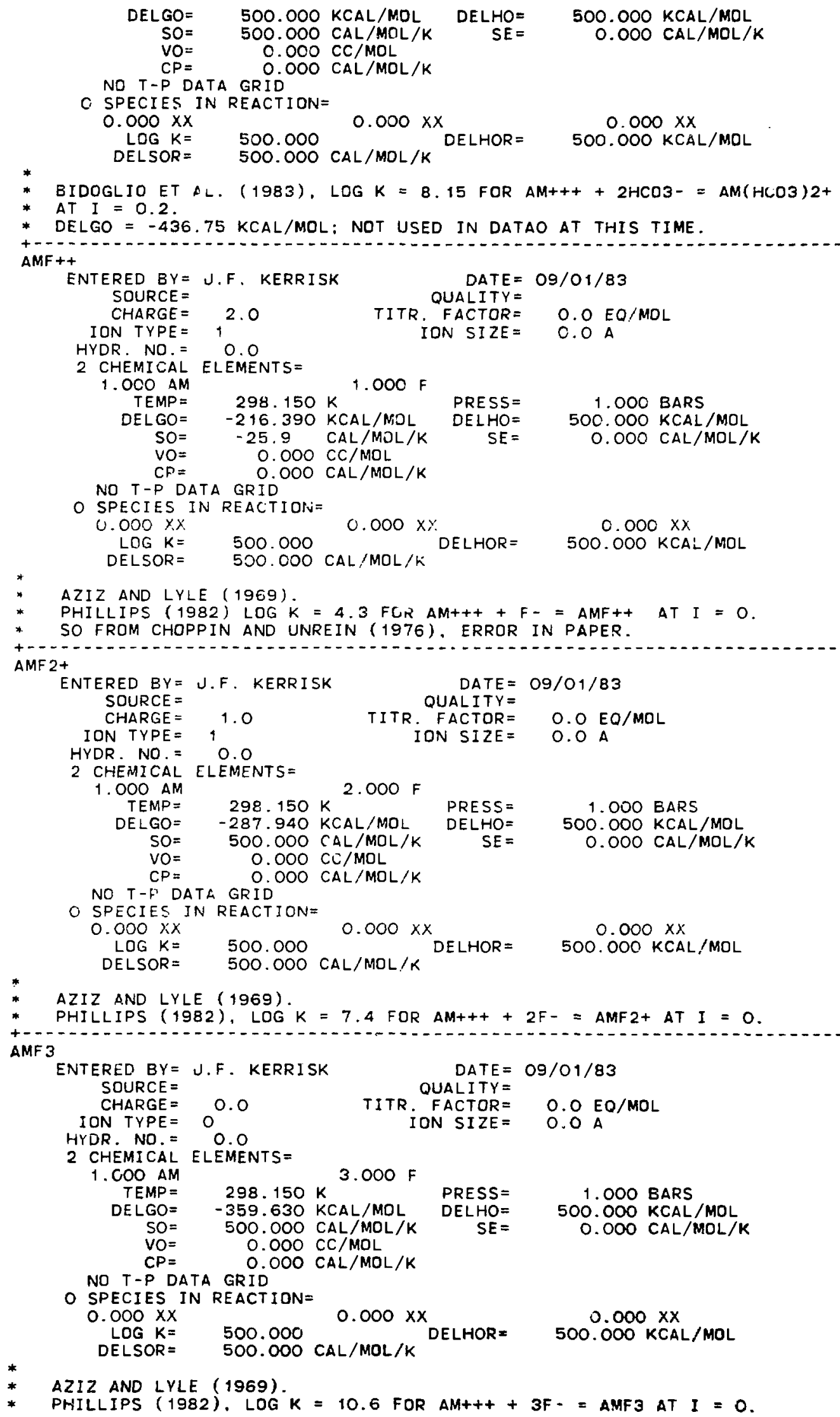




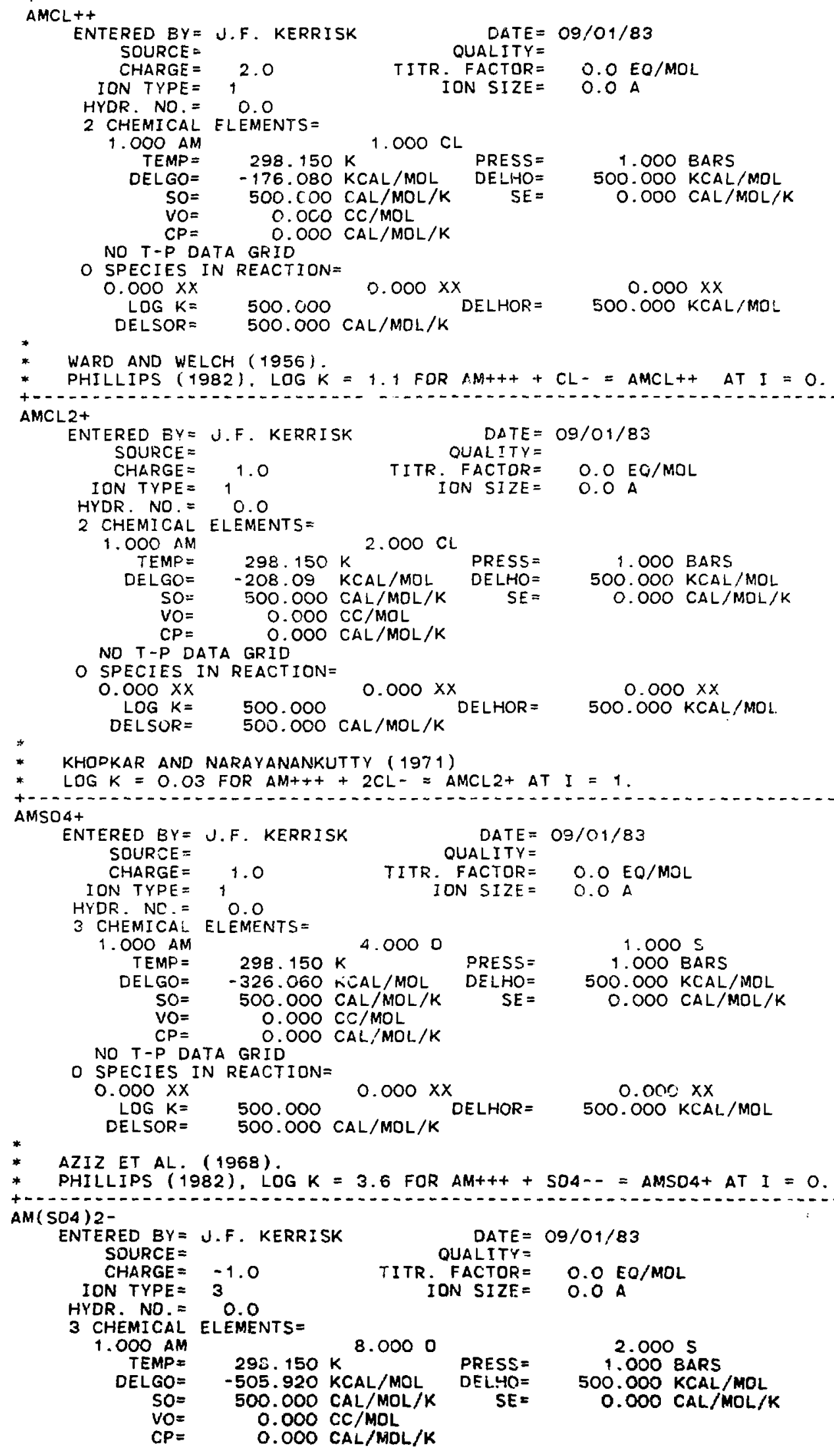

\section{$0.0 \mathrm{EO} / \mathrm{MOL}$ \\ $0.0 \mathrm{E}$
$0.0 \mathrm{~A}$}

8.0000

$\begin{array}{rr}\text { PRESS }= & 2.000 \mathrm{~S} \\ \text { DEL.4O }= & 500.000 \mathrm{KARS} \\ \text { SE }= & 0.000 \mathrm{KCAL} / \mathrm{MOL} \\ & \end{array}$




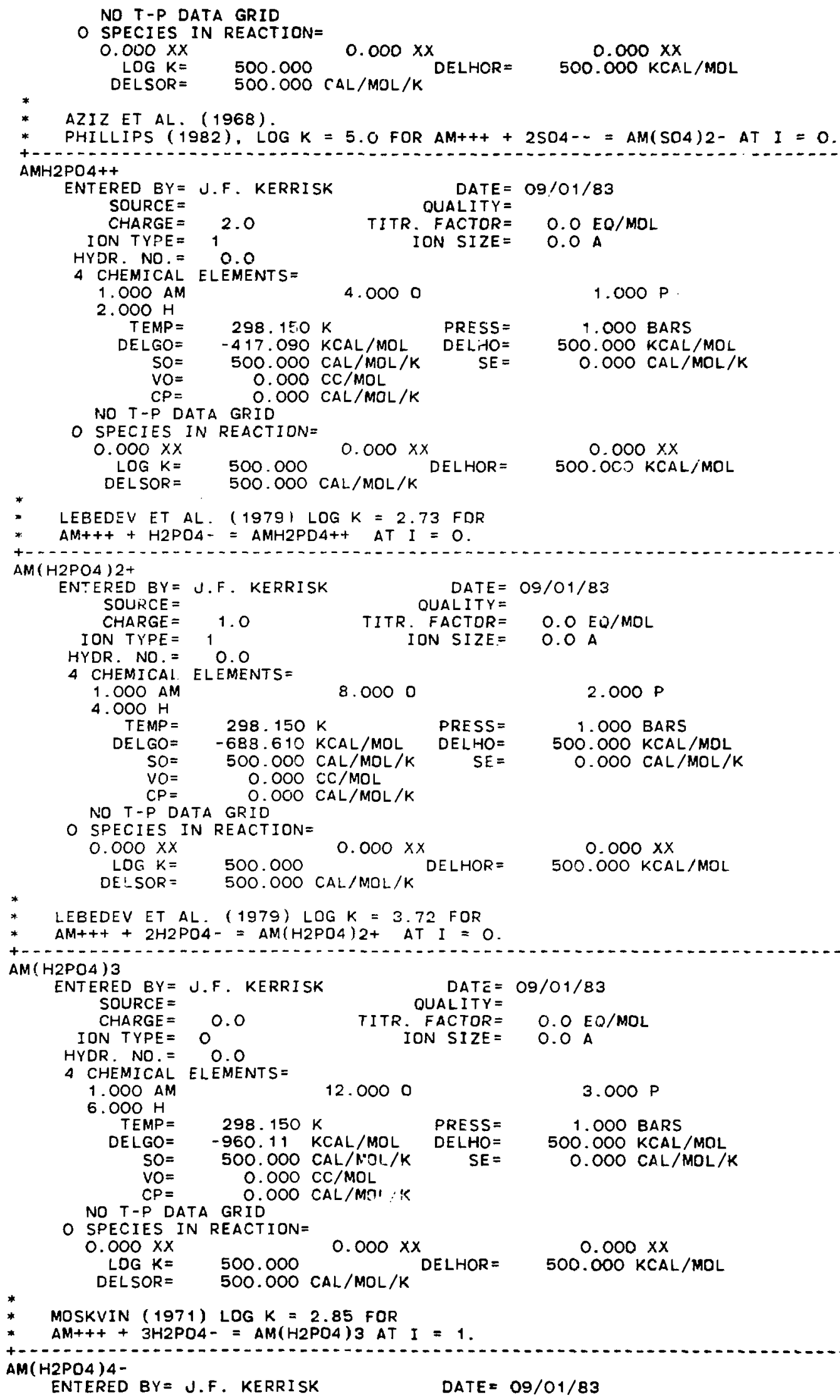




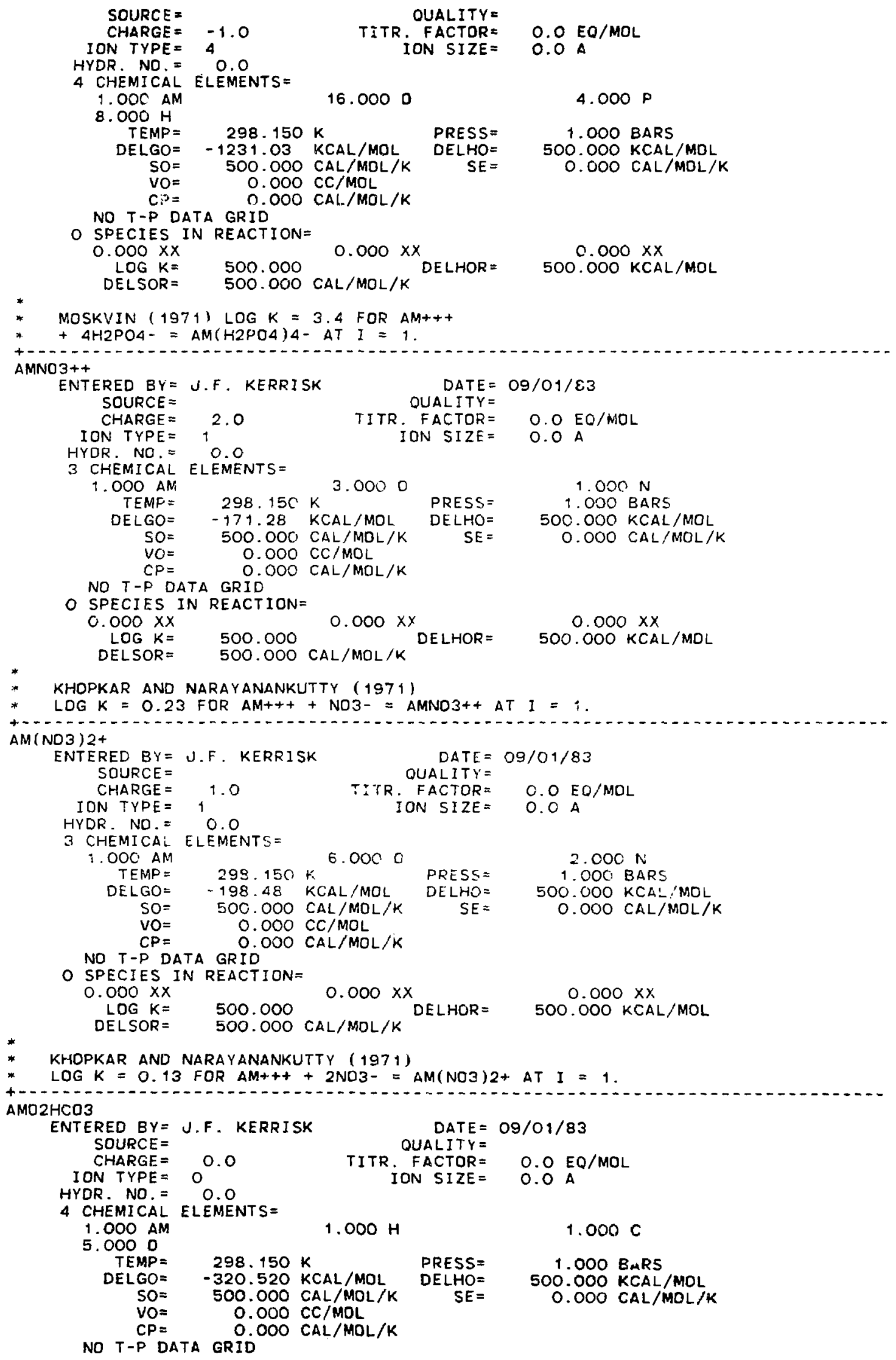




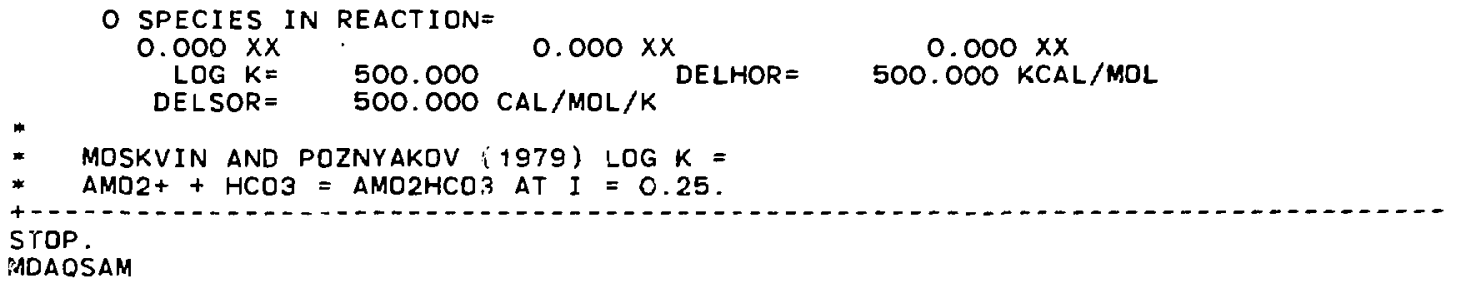

DATA ON AQUEOUS COMPLEXKES OF MANGANESE

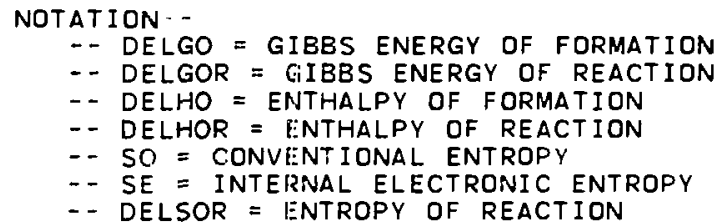

NOTE THAT "5OO." IS ENTERER TO MEAN "NO DATA" FOR DELGO, DELHO. SO, LOG K. DELHO. AND DELSOR. NEVER ENTER ZERO OR LEAVE BLATJK FOF THESE PARAMETERS UNLESS YOU MEAN TO USE AN ACTUAL VALUE OF ZERO.

IONIC STRENGTH CORRECTIONS NOTED IN THE ABOVE COMMENTS ON SPECIFIC SPECIES WERE MADE USING THE DAVIES EQUATION IN THE FORM

$\operatorname{LOG}($ GAMMA $)=0.51 *(Z * 22)((\operatorname{SORT}(I) /(1+\operatorname{SORT}(I)))-(0.2 * I))$

WHERE GAMMA IS THE ACTIVITY COEFFICIENT, $Z$ IS THE CHARGE, AND

I IS THE IONIC STRENGTH.

DATA FOR AOUEOUS SPECIES

NAME = AN ALPHABETIC OR ALPHANUMERIC STRING

ENTERED BY = NAME OF PERSON WHO ENTERED DATA DR LAST REVISED IT

DATE = DATA OF ENTERING OR REVISING DATA

SOURCE = ALPHANUMERIC STRING IDENTIFYING A MAJOR SOURCE OF DATA. USE

"SEE BELOW" FOR MINOF SOURCES

QUALITY = ALPHANUMERIC STRING DESCRIBING THE PFOBABLE ERROR IN GIBBS ENERGY OR ITS EQUIVALENT. BASED ON SUEJECTIVE JUDGEMENT AND CHOSEN FROM AMONG THE FDL:-OWING (IN ORDER DF INCREASING VALUE)

BAD - DEMCNSTRABLY BAD DATA- DO NOT USE EXCEPT IN ILLUSTRATIVE CALCULATIONS

PUOR - LIKELY ERROR EXCEEDS A COUPLE OF KCAL OF SEVERAL KU RESTRICTED - $A D$ HOC FIT TD A PARTICULAR SITUATION; SEE NOTES SPECULATIVE - SPECIES NOT SHOWN CONCLUSIVELY TO EXIST UNCERTAIN - CHOSEN RATHER ARBITRARILY FROM DIVERGENT REPORTED VALUES

UNSPECIFIED - NO QUALITY INFORMATION

(BLANK) - EQUIVALENT TO UNSPECIFIED

FAIR - LIKELY ERROR LESS THAN A COUPLE OF KCAL OR A FEW KJ GOOD - LIKELY ERROR LESS THAN ABOUT ONE KCAL OR FOUR KJ

THE CODE MUST BE MODIFIED TO ALLOW OTHER QUALITY PARAMETER INPUTS.

UNRECOGNIZED INPUTS ARE SET TO "ERROR". DATA FOR WHICH THE QUALITY IS "RESTRICTED", "SPECULATIVE", OR "UNCERTAIN" MAY NUMERICALLY BE

"FAIR" TO "GOOD". THE MAJOR UNCERTAINTY ASSOCIATED WITH THESE VALUES

IS QUALITATIVE (I.E., UNCERTAINTY OF INTERPRETATION). DATA FOR WHICH

THE QUALITY IS "POOR" MAY BE QUITE SUFFICIENT FOR MAKING "GOOD"

CALCULATIONS- THIS DEPENDS ON THI SENSITIVITY OF THE RESULTS TD IT IN

ANY PARTICULAR APPLICATIDN.

CHARGE = ELECTRICAL CHARGE

TITRATION FACTOR= WEIGHTING FACTOR FOR PH 4.5 (METHYL ORANGE)

ALKALINITY

ION TYPE = CRISS-COBBLE ION TYPE

O NEUTRA COMPLEX (MAY BE LEFT BLANK)

1 CATION (MAY BE LEFT BLANK)

2 SIMPLE ANION (MAY BE LEFT BLANK)

3 OXYANION

4 ACID OXYANION

ION SIZE = DEBYE-HUCKEL HYDRATED ION SIZE (FOR ACTIVITY COEFFICIENT EST IMATION)

HYDRATION NUMBER = NUMBER OF BOUND WATER MOLECULES NOT EXPLICITLY SHOWN IN THE ASSUMED MOLECUI.AR FORMULA (FOR ACTIVITY COEFFICIENT 
EST IMATION)

TEMP = THE BASE POINT TEMPERATURE ( $\mathrm{K}$ ). USUALLY $298.15 \mathrm{~K}$

PRESS = THE EASE POINT PRESSURE (BARS), USUALLY 1 BAR

DELGO= THE APPARENT STANDARD PARTIAL MOLAL GIBBS ENERGY AT THE

BASE POINT

DELHO = THE APPARENT STANDARD PARTIAL MOLAL ENTHALPY AT THE BASE POINT

$S O=$ THE CONVENTIONAL ENTROPY AT THE BASE POINT

$S E=$ THE INTERNAL ELECTRONIC ENTROPY; THIS FUNCTION IS ZERO E) ZEPT FOR SOME ACTINIDE AND RARE EARTH SPECIES (IT IS USED IN CRISS-COBBLE METHOD TEMPERATURE EXTRAPOLATIONS)

$V O=$ THE PARTIAL MOLAL VOLUME AT THE BASE POINT; THERE IS NO CURRENT PROVISION FOR USING THIS INPUT IN THE CURRENT MCRT (AS OF 12/16/82)

CP = THE PARTIAL MOLAL HEAT CAPACITY AT THE BASE POINT; THERE IS NO CURRENT PROVISION FOR USING THIS INPUT IN THE CURRENT MCRT (AS OF $12 / 16 / 82$ )

LOG K= LOG OF THE EOUILIBRIUM CONSTANT OF THE GIVEN REACTION AT THE BASE POINT

DELHOR = ENTHALPY OF THE GIVEN REACTION AT THE 3ASE POINT

DELSOR = ENTRCPY DF THE GIVEN REACTION AT THE BASE POINT

\section{REFERENCES}

AZIZ, A., LYLE, S., AND NAOVI, S. , 1968, CHEMICAL EQUILIBRIA IN AMERICIUM AND CURIUM SULPHATE AIND OXALATE SYSTEMS AND AN APPLICATION OF A LIOUIU SCINTILLATION COUNTING METHOD. JOUR. INERA. NUCL. CHEM., 30, 1013-1018.

AZIZ, A. AND LYLE, S.. 1969, EOUILIBRIUM CONSTANTS FOR AOUEOUS FLUORO COMPLEXES OF SCANDIUM, YTTRIUM. AMERICIUM(III) AND CURIUM(III) BY EXTRACTION INTO DI-2-ETHYLHEXYL PHOSPHDRIC ACID, JOUR. INORG. NUCL. CHEN., 31, 3471-3480

BAES, C. F. JR. AND MESMER, R. E., 1976, THE HYDROLYSIS OF CATIONS, JOHN WILEY AND SONS, NEW YORK. PP. 191-192.

BIDOGLIO, G.. DE PLANO, A., AND CHATT. A.. 1983, STUDIES ON SPECIATION OF AMERICIUM, TECHNECIUM AND NEPTUNIUM IN SIMULATED VITRIFIED-WASTE LEACHATES. IN BROOKINS, G. (ED.). SCIENTIFIC BASIS FOR NUCLEAR WASTE MANAGEMENT VI, SYMDOSIUM HELD NOVEMBER 1982, BOSTON, MASSACHUSETTS, VOLUME 15 OF MATERIALS RESEARCH SOCIETY SYMPOSIUM PROCEEDINGS, NORTH-HOLLAND, NEW YORK; SEE ALSO BIDOGLID, G., 1982, CHARACTERIZATION OF AM(III) COMPLEXES WITH BICARBONATE AND CARBONATE IONS AT GROUNDWATER CONCENTRATION LEVELS. RADIOCHEM?CAL AND RADIOANALYTICAL LETTERS, 53, 45-60.

CHOPPIN, G. AND UNREIN. F., 1975. THERMOOYNAMIC STUDY OF ACTINIDE FLUARIDE COMPLEXATION. IN MULLER, $W$. ANO LINDER, $R$, (EDS.). TRANSPLUTONIUM $1975,4 T H$ INTERNATIONAL TRANSPLUTONIUM SYMPOSIUM. BADEN-BADEN, GERMANY, SEPTEMBER $13-17,1975$ NORTH-HOLLAND, NEW YORK. APPARENT ERROR IN DELHR AND DELSR FOR AM IN TABLE 2 OF PAPER. KERRISK CALCULATES DELHR $=3.3$ AND DELSR $=25.3$.

FERRI, D. , GRENTHE, I . HIETANEN, S. AND SALVATORE, F., 1983. STUDIES ON METAL CARBONATE EQUILIBRIA. 5. THE CERIUM(III) CARBDNATE COMPLEXES IN AOUEDUS PERCHLDRATE MEDIA, SUBMITTED TD ACTA CHEMICA SCAND.

FUGER, J. AND OETTING, F. L., 1976, THE CHEMICAL THERMODYNAMICS OF ACTINIDE ELEMENTS AND COMPOUNDS, PART 2, THE ACTINIDE AQUEDUS IONS. INTERNATIONAL ATOMIC ENERGY AGENCY, VIENNA.

KHOPKAR, P. AND NARAYANANKUTTY, P. 1979, EFFECT OF IONIC MEDIA ON THE STABILITY CONSTANTS OF CHLORIDE. NITRATE AND THIOCYANATE COMPLEXES OF AMERICIUM(III) AND EUROPIUM(III), JDUR. INORG.

NUCL. CHEM. , 33, 495-502.

KIM J. BERNKOPF, M. LIERSE, CH. AND KOPPOLD, F. 1983A, HYDROLYSIS REACTIONS OF AM(III) AND PU(VI) IN NEAR NEUTRAL SOLUTIONS, PRESENTED AT THE 185TH MEETING OF THE AMERICAN CHEMICAL SOCIETY, SEATTLE, WASHINGTON, MARCH, 1983. PARER NO, 91.

KIM J.. PRIVATE COMMUNICATION, MARCH, 1983.

LEBEDEV, I F FRENKEL, V., KULYAKO, YU. AND MYASOEDDV, F . 1979 , INVESTIGATION OF COMPLEX FORMATION OF AMERICIUM(III) AND 
AMERICIUM(IV) IN PHOSPHORIC ACID SOLUTIONS. RADIOKHIMIYA (ENGLISH TRANS.) , 21, 809-816.

LUNDOVIST, R., 1982, HYDROPHILIC COMPLEXES OF THE ACTINIDES. I. CARBONATES OF TRIVALENT AMERICIUM AND EUROPIUM, ACTA CHEMICA SCAND. A, 36, 741-750.

MCGLYNN, S. AND SMITH, J., 1961, THE ELECTRONIC STRUCTURE, SPECTRA. AND MAGNETIC PROPERTIES OF ACTINYL IONS. PART II. NEPTUNYL. AND THE GROUND STATES OF OTHER ACTINYLS, JOUR. MOLECULAR SPECTR:SCOPY. 6. $188-198$.

MOSKVIN. A. 1971, INVESTIGATION OF THE COMPLEX FORMATION OF TRIVALENT PLUTDNIUM, AMERICIUM. AND CURIUM IN PHOSPHATE SOLUTIDNS, RADIOKHIMIYA (ENGLISH TRANS.). 13, 668-674.

MOSKVIN, A. AND POZNYAKOV, A.. 1979, COPRECIPITATION STUDY OF COMPLEX FORMATION BY NEPTUNIUM(V), PLUTONIUMIV), AND AMERICIUM(V) WITH THE ANIONS OF VARIOUS INORGANIC ACIDS. ZHURNAL NEORGANICHESKOI KHIMMI (ENGLISH TRANS.), 24, 2449-2457.

PHILLIPS, S. L., 1982, HYDROLYSIS AND FORMATION CONSTANTS AT 25 C LAWRENCE BERKELEY LABORATORY REPORT LEL-14313.

SHALINETS, A. AND STEPANOV. A., 1972, INVESTIGATION OF COMPLEX FORMATION OF THE TRIVALENT ACTINIDE AND LANTHANIDE ELEMENTS BY THE METHOD OF ELECTRONIGRATION XVII. HYDROLYSIS. RADIOKHIMIYA (ENGLISH TRANS.) 14, 290-293.

SILVA, R., 1982. THE SOLUBILITIES OF CRYSTILLINE NEODYMILM AND AMERICIUM TRIHYDRDXIDES. LAWRENCE BERKELEY LABORATORY REPORT LBL- 15055 .

WARD. M. AND WELCH, G., 1956, THE CHLORIDE COMPLEXES UF TRIVALENT PLUTONIUM, AMERICIUM, AND CURIUM, JOUR. INORG. NUCL. CHEM. 2 , 395-402.

STOP. 


\section{APPENDIX B}

Appendix $B$ contains a listing of the input file MDSOL for the MCRT

program. This file contains thermodynamic data for solid species of americium. 


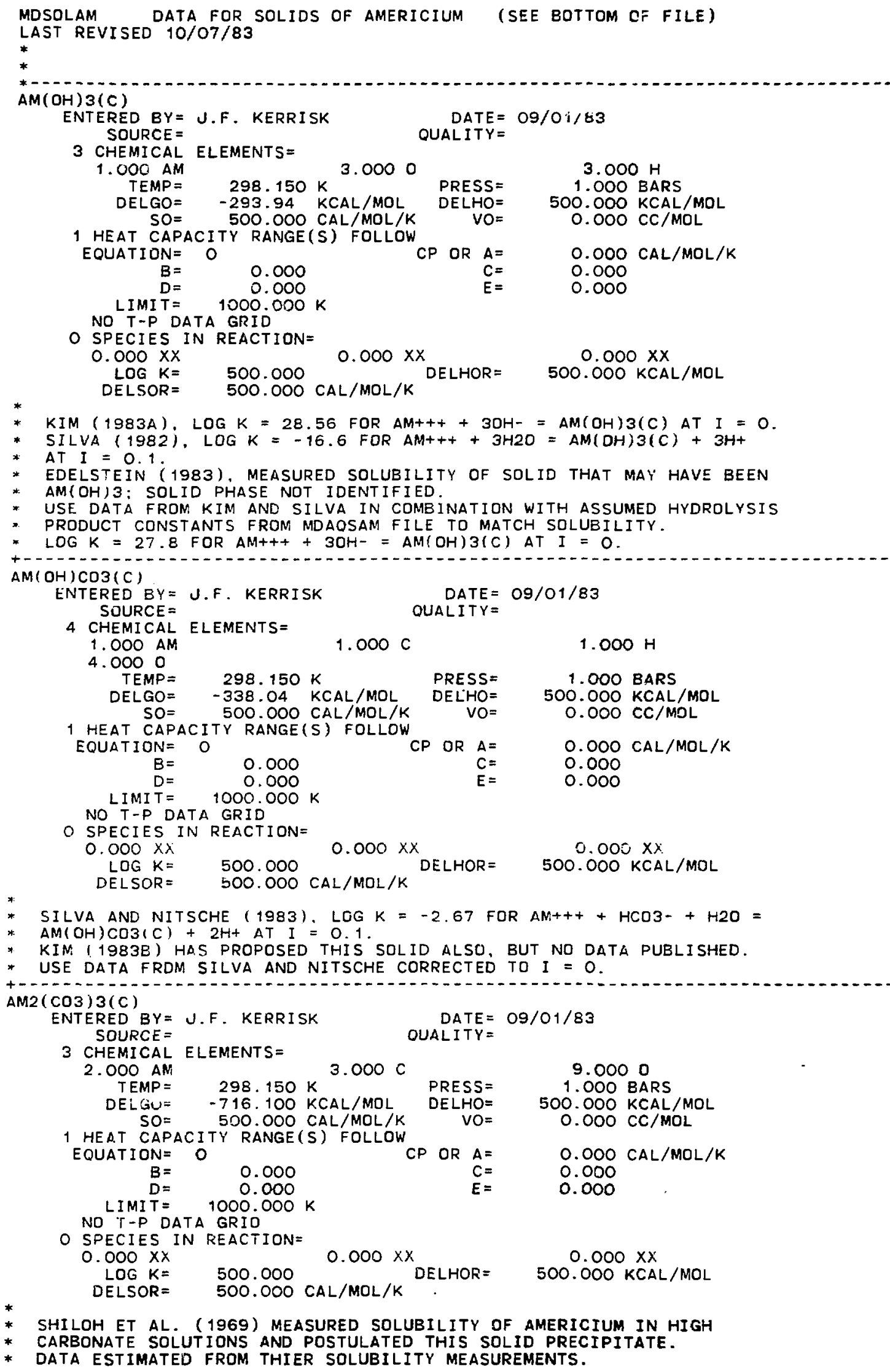

DATE $=09 / 01 / 83$ OUALITY

SHILOH ET AL. (1969) MEASURED SOLUBILITY OF AMERICIUM IN HIGH CARBONATE SOLUTIONS AND POSTULATED THIS SOLID PRECIPITATE. DATA ESTIMATED FROM THIER SOLUBILITY MEASUREMENTS. 


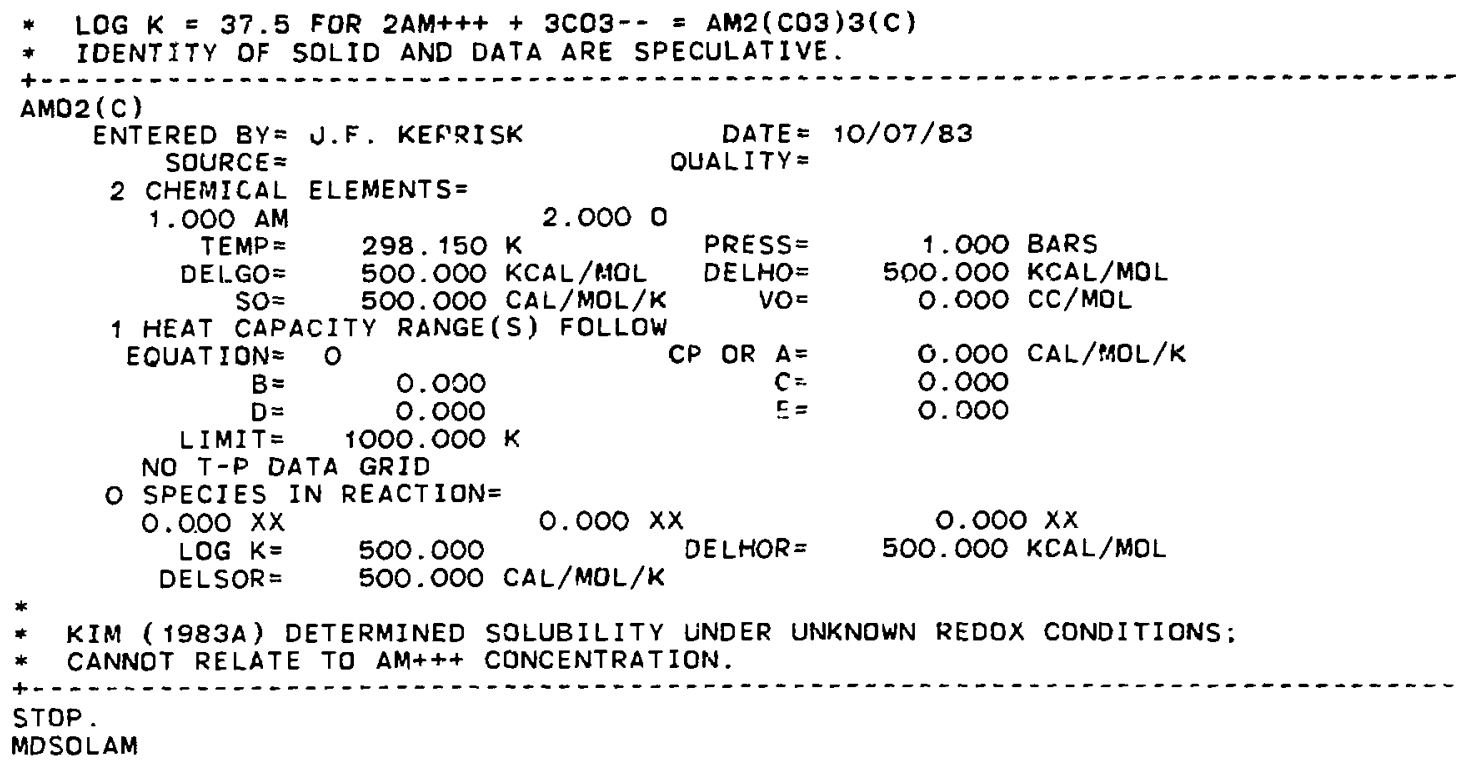

DATA ON MINERALS AND RELATED SUBSTANCES OF AMER:CIUM

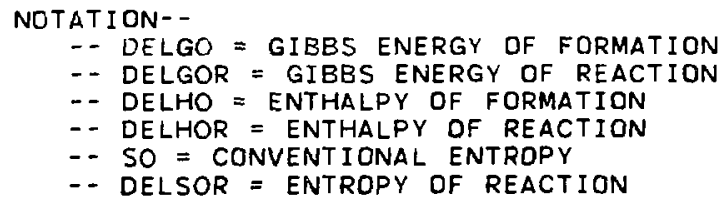

NOTE THAT "500." IS ENTERED TO MEAN "NO DATA" FOR DELGO, DELHO. SO. DELHTR, DELSTR, LOG K, DELHO. AND DELSOR. NEVER ENTER ZERO FOR THESE PARAMETERS OR LEAVE THEM BLANK UNLESS YOU MEAN TO USE AN ACTUAL VALUE OF ZERO. $1000 \mathrm{~K}$ IS THE DEFAULT FOR THE "LIMIT" PARAMETER.

IONIC STRENGTH CORRECTIONS WERE MADE USING THE DAVIES EQUATION IN THE FORM

LOG(GAMMA $)=0.51 *(2 * 2)((\operatorname{SORT}(I) /(1+\operatorname{SORT}(I)))-(0.2 * I))$

WHERE GAMMA IS THE ACTIVITY COEFFICIENT, 2 IS THE CHARGE, AND I IS THE IONIC STRENGTH.

\section{DATA FDR SOLID/GAS SPECIES=}

NAME $=$ AN ALPHABETIC OR ALPHANUMERIC STRING; E.G., CALCITE. BISCHOFITE. THE FORMULA MAY ALSO BE USED AS THE NAME.

FORMULA = AN ALPHANUMERIC STRING DENOTING THE FORMULA OF THE SPECIES:

E.G. CACO3. MGCL2.6H2O.

ENTERED BY = NAME OF PERSON WHO ENTERED DATA OR LAST REVISED IT

DATE = DATA OF ENTERING OR REVISING DATA

SOURCE = ALPHANUMERIC STRING IDENTIFYING A MAUDR SDURCE OF DATA. USE "SEE BELOW" FOR MINOR SOURCES

QUALITY = ALPHANUMERIC STRING DESCRIBING THE PROEABLE ERROR IN GIBBS ENERGY OR ITS EQUIVALENT. BASED ON SUBJECTIVE JUDGEMENT AND CHOSEN FROM AMONG THE FOLLOWING (IN ORDER OF INCREASING VALUE)

BAD - DEMONSTRABLY BAD DATA - DO NOT USE EXCEPT IN ILLUSTRATIVE CALCULATIONS

POOR - LIKELY ERROR EXCEEDS A COUPLE OF KCAL OR SEVERAL KJ RESTRICTED - AD HOC FIT TO A PARTICULAR SITUATION: SEE NOTES SPECULATIVE - SPECIES NOT SHOWN CDNCLUSIVELY TO EXIST UNCERTAIN - CHOSEN RATHER ARBITRARILY FRDM DIVERGENT REPORTED VALUES

UNSPECIFIED - NO QUALITY INFORMATION

(BLANK) - EOUIVALENT TO UNSPECIFIED

FAIR - LIKELY ERROR LESS THAN A COUPLE OF KCAL OR A FEW KUJ

GODD - LIKELY ERROR LESS THAN ABOUT DNE KGAL DR FOUR KJ

THE CODE MUST BE MODIFIED TO ALLOW DTHER QUALITY PARAMETER INPUTS. 
UNRECOGNIZED INPUTS ARE SET TO "ERROR". DATA FOR WHICH THE OUALITY IS "RESTRICTED" "SPECULATIVE", DR "UNCERTAIN" MAY INUMERICALLY BE. "FAIR" TO "GOOD". THE MAJDR UNCERTAINTY ASSOCIATED WITH THESE VALUES

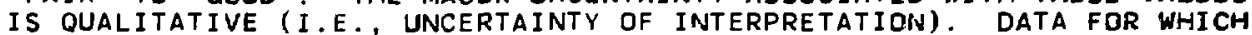
THE OUALITY IS "POOR" MAY BE OUITE SUFFICIENT FOR MAKING "GOOD" CALCULATIONS- THIS DEPENDS ON THE SENSITIVITY OF THE RESULTS TO IT IN ANY PARTICULAR APPLICATION.

NUMBER OF CHEMICAL ELEMENTS PER MOLE

NUMBER OF MOLES OF ELEMENT PER MOLE OF SLBSTANCE

SYMBOL OF CHEMICAL ELEMENT

TEMP= THE BASE POINT TEMPERATURE (K), USUALLY $298.15 \mathrm{~K}$

PRESS = THE BASE POINT PRESSURE (BARS), USUALLY 1 . BAR

DELGO = THE APPARENT STANDARD PARTIAL MOLAL GIBBS ENERGY AT'THE

BASE POINT

DELHO = THE APPARENT STANDARD PARTIAL MOLAL ENTHALPY AT THE BASE POINT

SO = THE CONVENTIONAL ENTROPY AT THE BASE POINT

VO= THE MOLAR VOLUME AT THE BASE POINT

NUMBER OF HEAT CAPACITY RANGES THAT FOLLOW

EQUATION = HEAT CAPACITY EQUATION CODE

$0-\quad C P=A+1 \cdot E-3 * B * T+1, E+5 * C * T *(-2)+1, E-6 * D * T * 2$

$1-C P=A+1 \cdot E-3 * B * T+1 \cdot E+5 * C * T *(-2)+1 \cdot E+8 * D * T * *(-3)$

$C P=$ THE MOLAR HEAT CAPACITY, ASSUMED TO BE A CONSTANT

$A=$ FIRS $T$ HEAT CAPACITY COEFFICIENT

$B=$ SECOND HEAT CAPACITY COEFFICIENT

$C=$ THIRD HEAT CAPACITY COEFFICIENT

$D=$ FOURTH HEAT CAPACIT' $;$ COEFFICIENT

$E=$ FIFTH HEAT CAFACITY COEFFICIENT

LIMIT = UPPER LIMIT $(K)$ OF IHE PRECEDING SET OF HEAT CAPACITY PARAMETERS:

NO T-P LATA GRID

THIS IS EITHER THE UPPER LIMIT OF USE BASED ON THE RANGE OF MEASUREMENT

OR THE TEMPERATURE OF A PHASE TRANSITION

DELHTR = ENTHALPY OF A PHASE TRANSITION, IF ANY

DELSTR = ENTROPY OF A PHASE TRANSITION, IF ANY

T-P DATA GRID INDICATION LINE, FOLLOWED BY T-P DATA GRID. IF ANY

TEMP. PRESS, DELGO, DELHO, SO, VO

NUMBER OF SPECIES APPEARING IN A REACTION. IF A REACTION FOLLOWS

NUMBER OF MOLES OF A SPECIES APPEARING IN THE REACTION

THE NAME OF THE CORRESPONDING SPECIES

LOG K= LOG OF THE EQUILIBRIUM CONSTANT OF THE GIVEN REACTION AT THE

BASE POINT

DELHOR = ENTHALPY OF THE GIVEN REACTION AT THE BASE POINT

DELSOR = ENTROPY OF THE GIVEN REACTION AT THE BASE POINT

REFERENGES

BAES. C. F. A'R. AND MESMER, R. E.. 1976. THE HYDROLYSIS OF CATIONS. JOHI WILEY ANE SONS.NEW YORK. PP. 191-192.

EDELSTEIN, N. BUCHER, J. SILVA, R. AND NITSCHE, H., 1983, THERMODYNAMIC PROPERTIES OF CHEMICAL SPECIES IN NUCLEAR WASTE, LAWRENCE BERKELEY LABORATORY REFORT LBL-14325.

KIM J. EERNKOPF, M. . LIERSE, CH. , AND KOPPOLD, F. . 19834. HYDROLYSIS REACTIONS OF AM(III) AND PU(VI) IN NEAF NEUTRAL SOLUTIONS. PRESENTED AT THE 185TH MEETING OF THE AMERICAN CHEMICAL SDCIETY. SEATTLE, WASHINGTON. MARCH, 1983, PARER NO. 99.

KIM J., PRIVATE COMMUNICATION. MARCH, 1983.

SHILOH, M. GIVON, M. A AND MARCUS, Y.. 19E9. A SPECTROPHOTOMETRIC STUDY OF THE TRIVALENT ACTINIDE COMPLEXES IN SOLUTION - II:". AMERICIUM WITH BROMIDE, IODIDE, NITRATE AND CARBONATE LIGANDS JOUR. INDRG. NUCL. CHEM. . 31. 1807-1814. PAPER GIVES SOLUBILITY OF AMERICIUM IN CARBONATE SOLUTIONS. KERRISK CALCULATED LOG K FOF. SOLUEILITY REACTION FROM SOLUEILITY DATA.

SILVA, F., 19EA. THE SOLUEILITIES OF ER:STALIINE NECDYMIUN, AND AMERICIUM TRIHYDROXIDES. LAWRENCE EERKELEY LAEORLTORY REPDRT LEL - 15055 .

SILVA, R. AND NITSCHE, H. 1984. THERMODYNAMIC PROPERTIES OF CHEMICAL SPECIES OF WASTE RADIONUCLIDES, IN NRE NUCLEAR WASTE GEOCHEMISTRY 83, D. H. ALEXANDER AND G. F. BIRCHARD (EDS.), $U$. S. NUCLEAR REGULATORY COMMISSION REPORT NUREG/CP-0052 (MAY 1984).

STOP. 


\section{APPENDIX C}

Appendix $C$ contains a listing of the input $f$ ile REAC for the MCRT program. This file defines the chemical reactions of americium species that were considered. 
RUN BY $=$ J. F. KERRISK

DATE $=09 / 01 / 83$

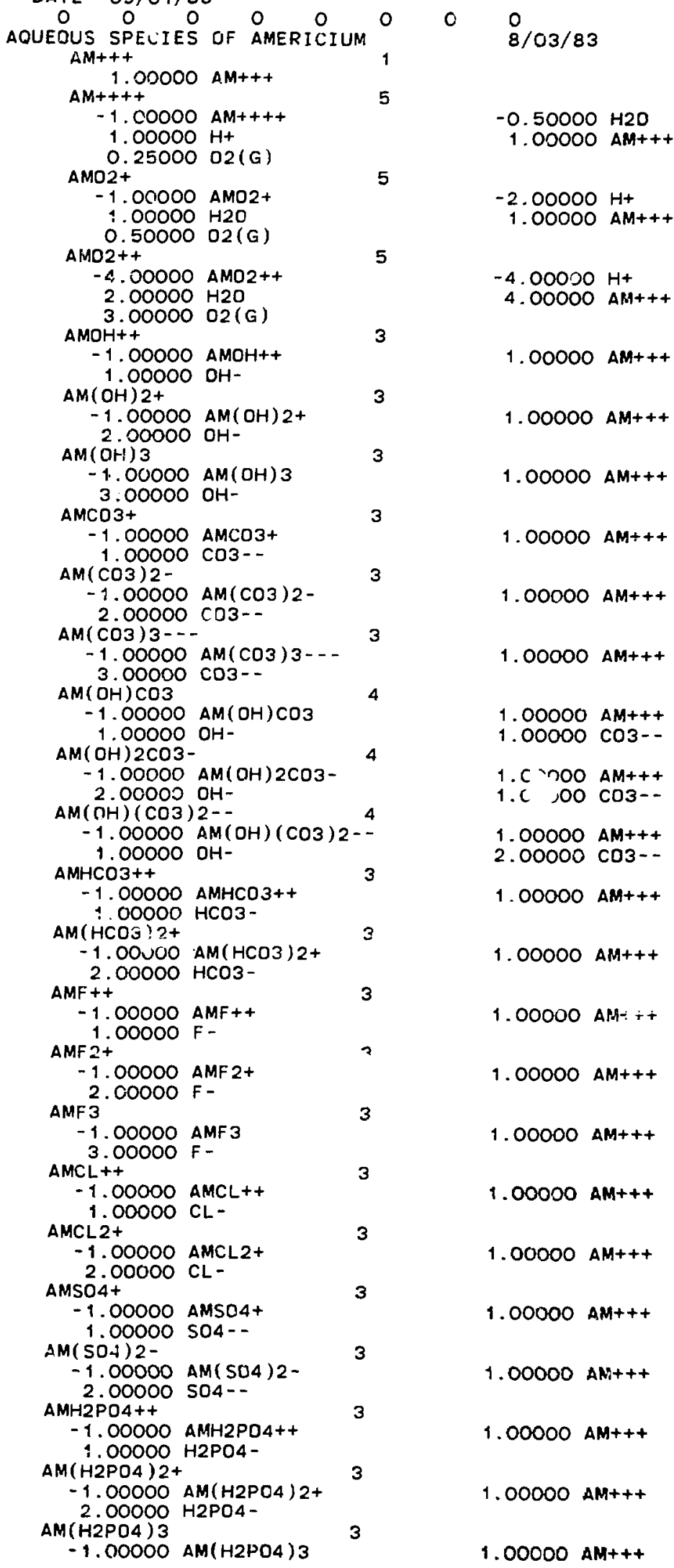




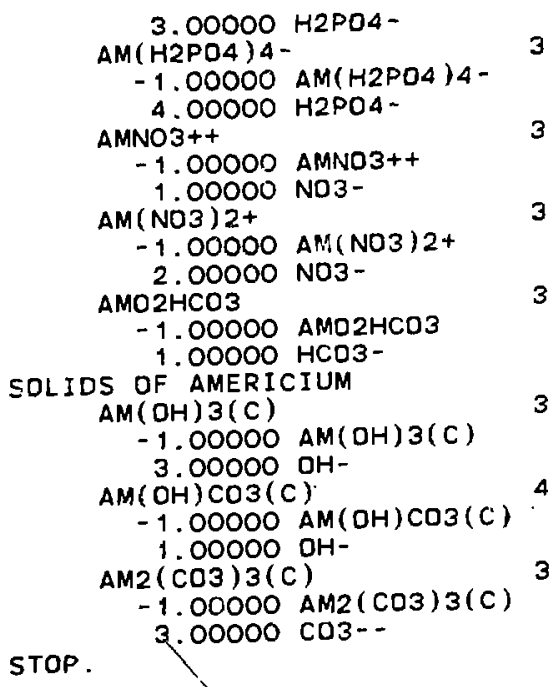

3

3

3

$+\quad 1.20000 \mathrm{AMO}^{+}$

$8 / 03 / 83$

$1.00000 \mathrm{AM+++}$

$1.00000 \mathrm{Am+++}$

$1.00000 \mathrm{CO} 3--$

$2.00000 \mathrm{AM+++}$ 
APPENDIX D

Appendix $D$ contains a listing of the output file DFILE from the MCRT program. This file contains the equilibrium-constant data for the reactions specified in Appendix C. 


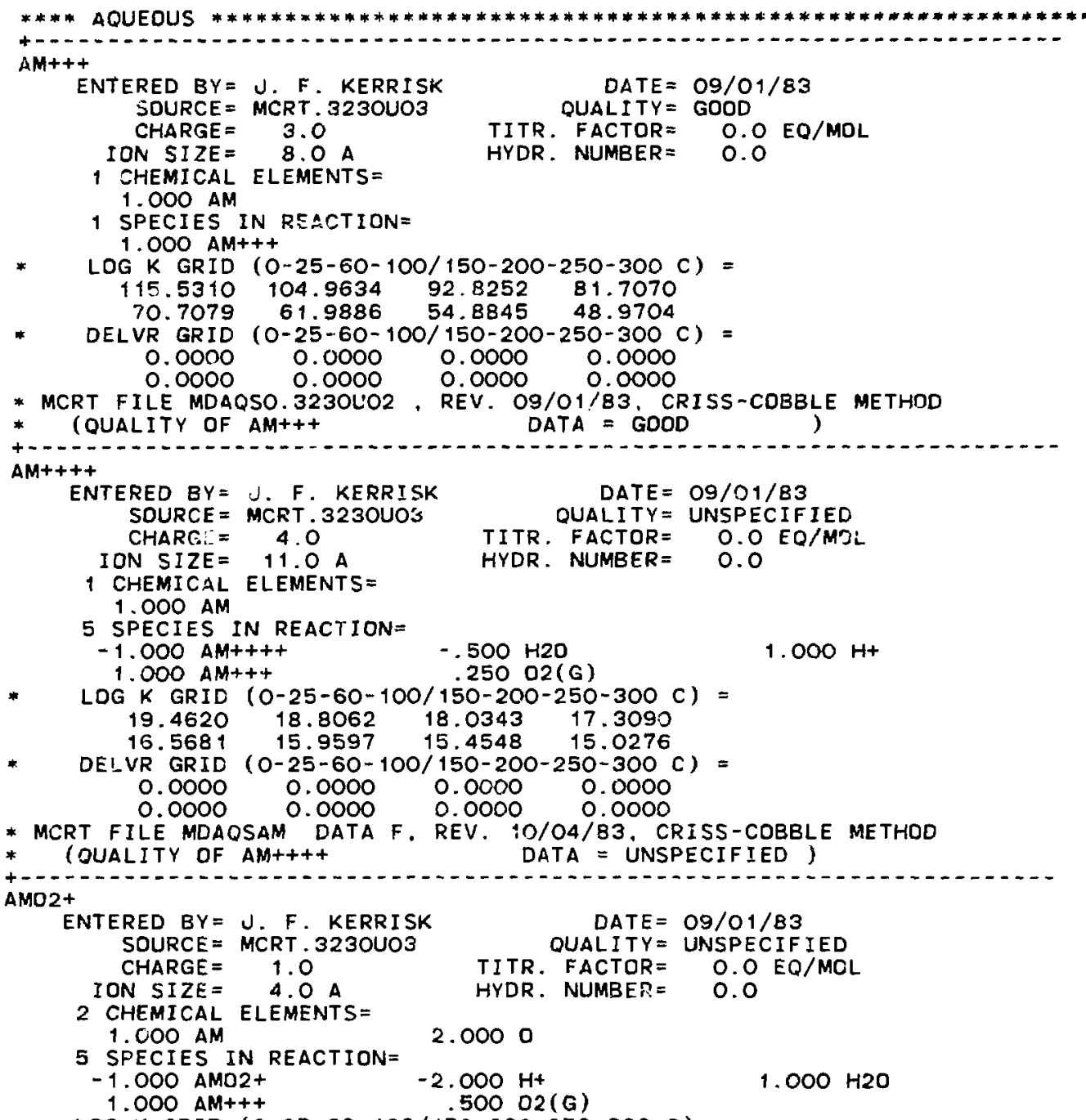




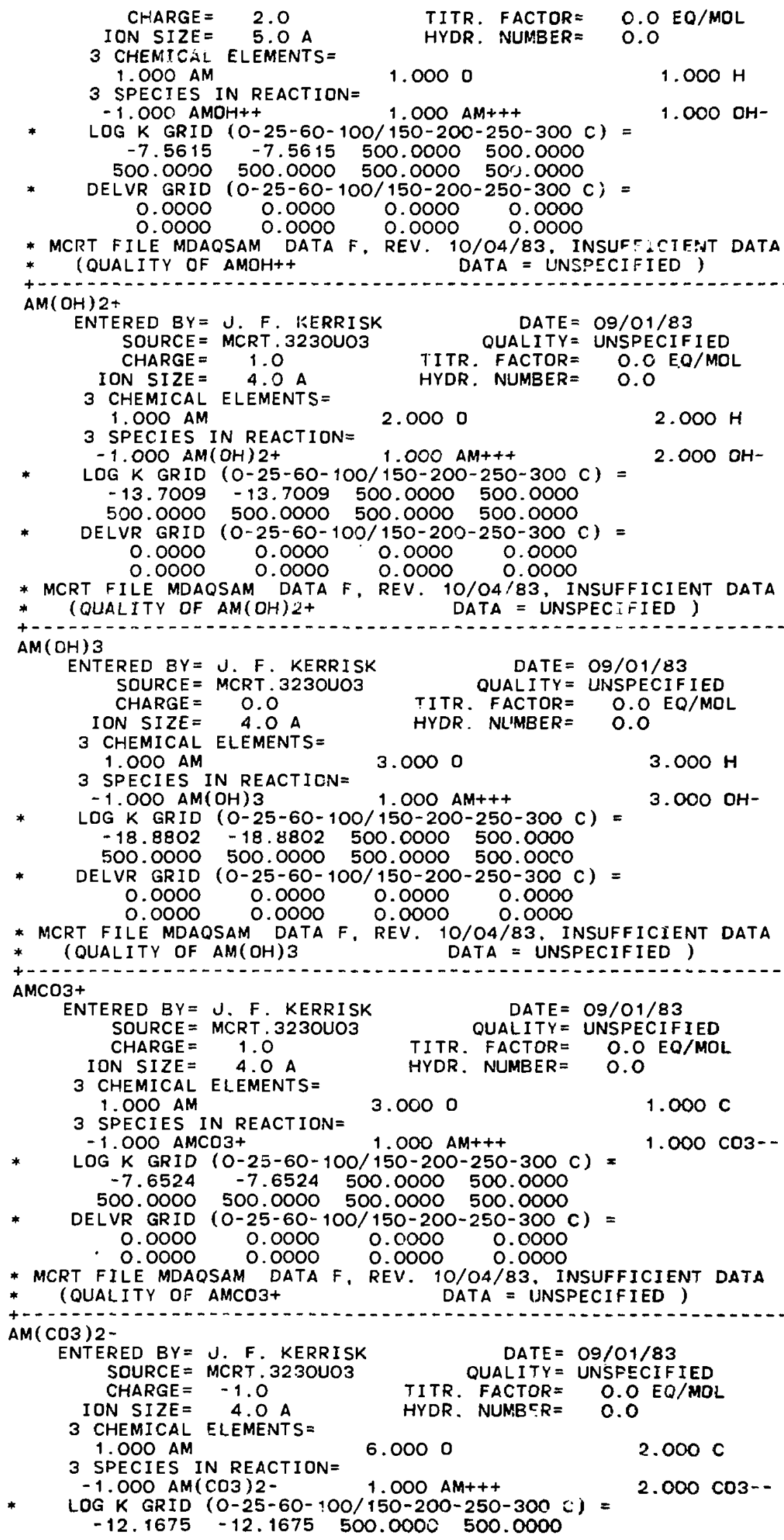

* LOG K GRID $(0-25-60-100 / 150-200-250-300 \mathrm{C})=$

$D A T E=09 / 01 / 83$

TITR. FACTOR= $0.0 \mathrm{EQ} / \mathrm{MOL}$

0.0

$1.000 \mathrm{c}$

$1.000 \mathrm{co3}--$

$2.000 \mathrm{co3}-$ 


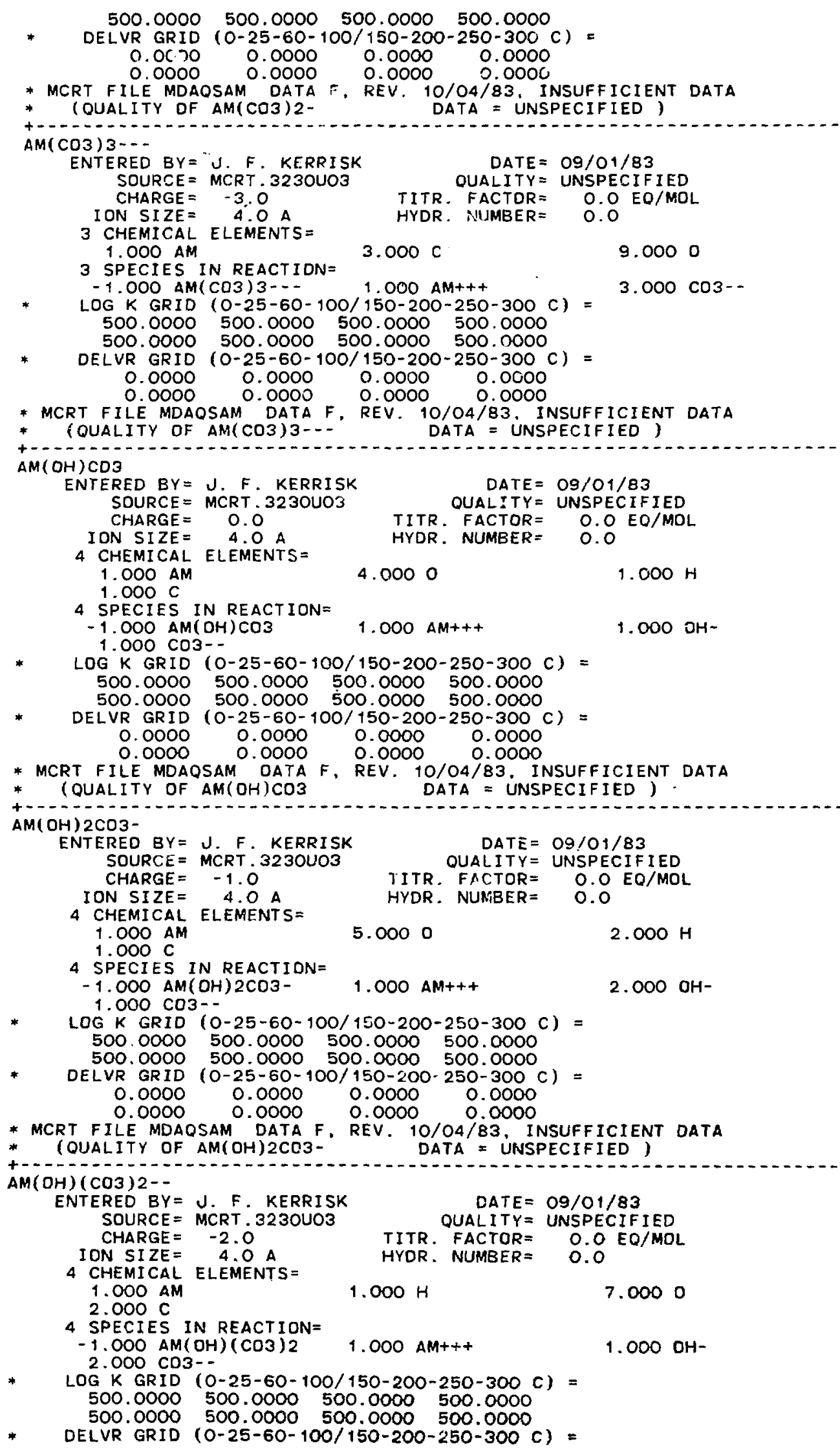




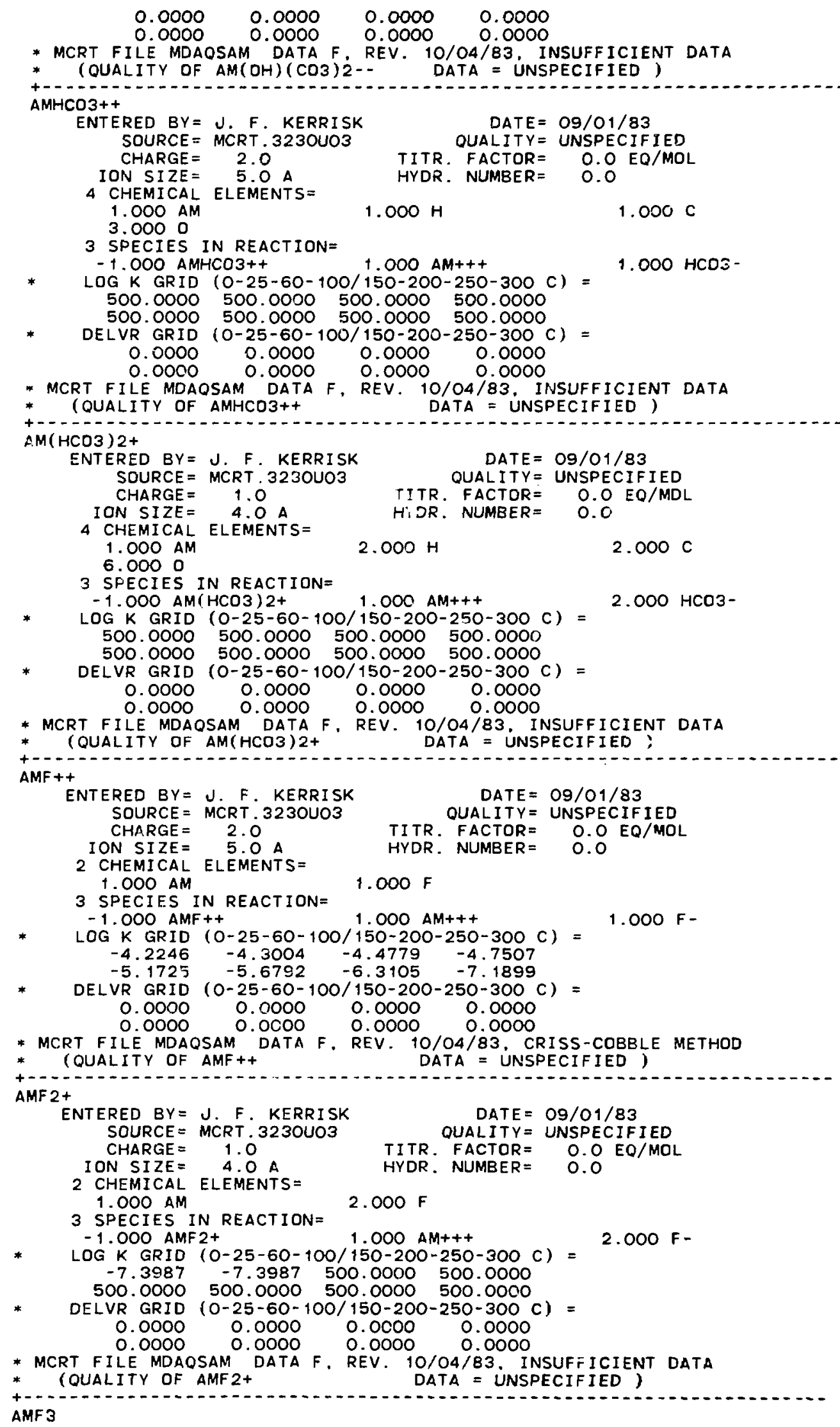




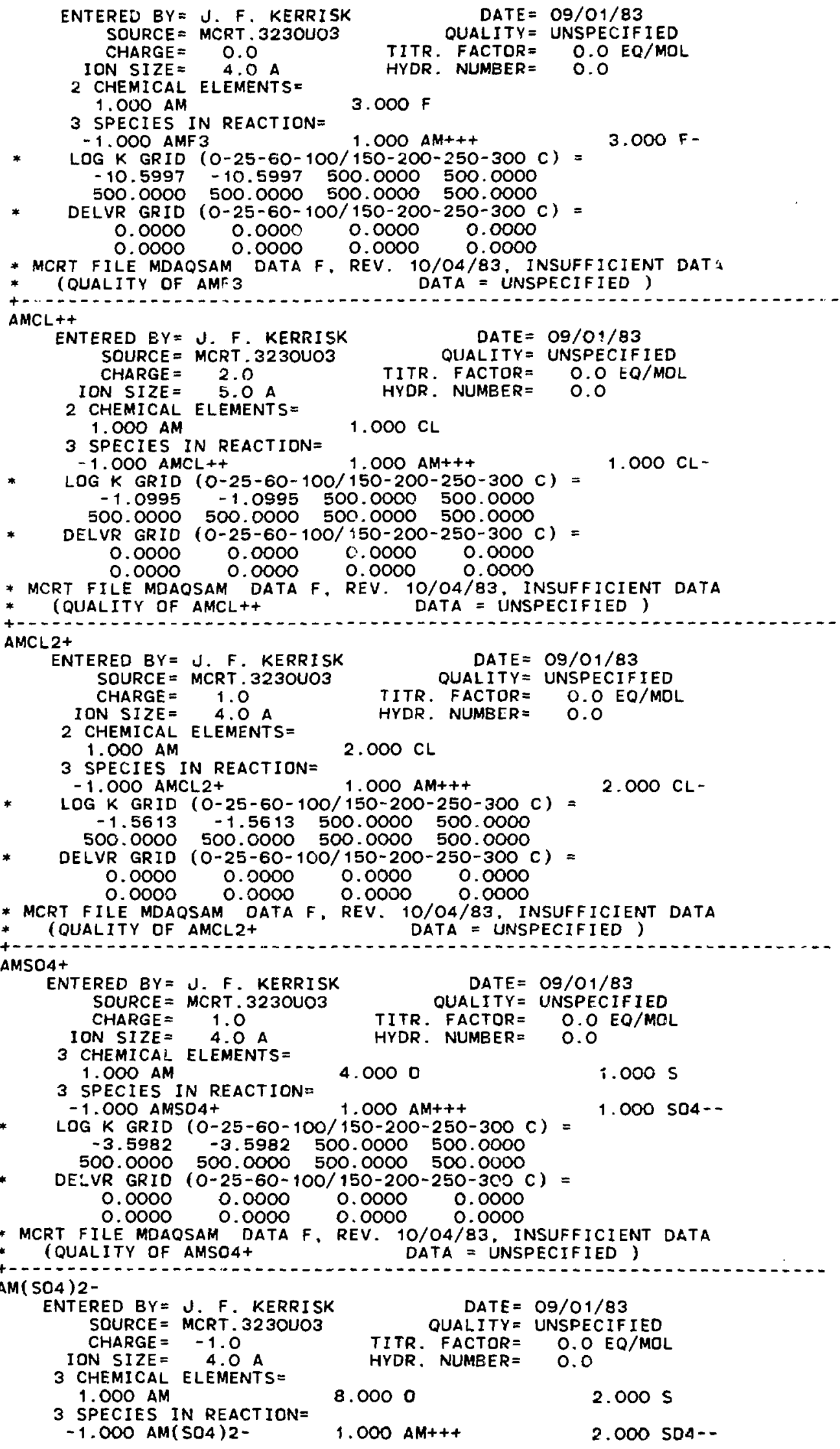




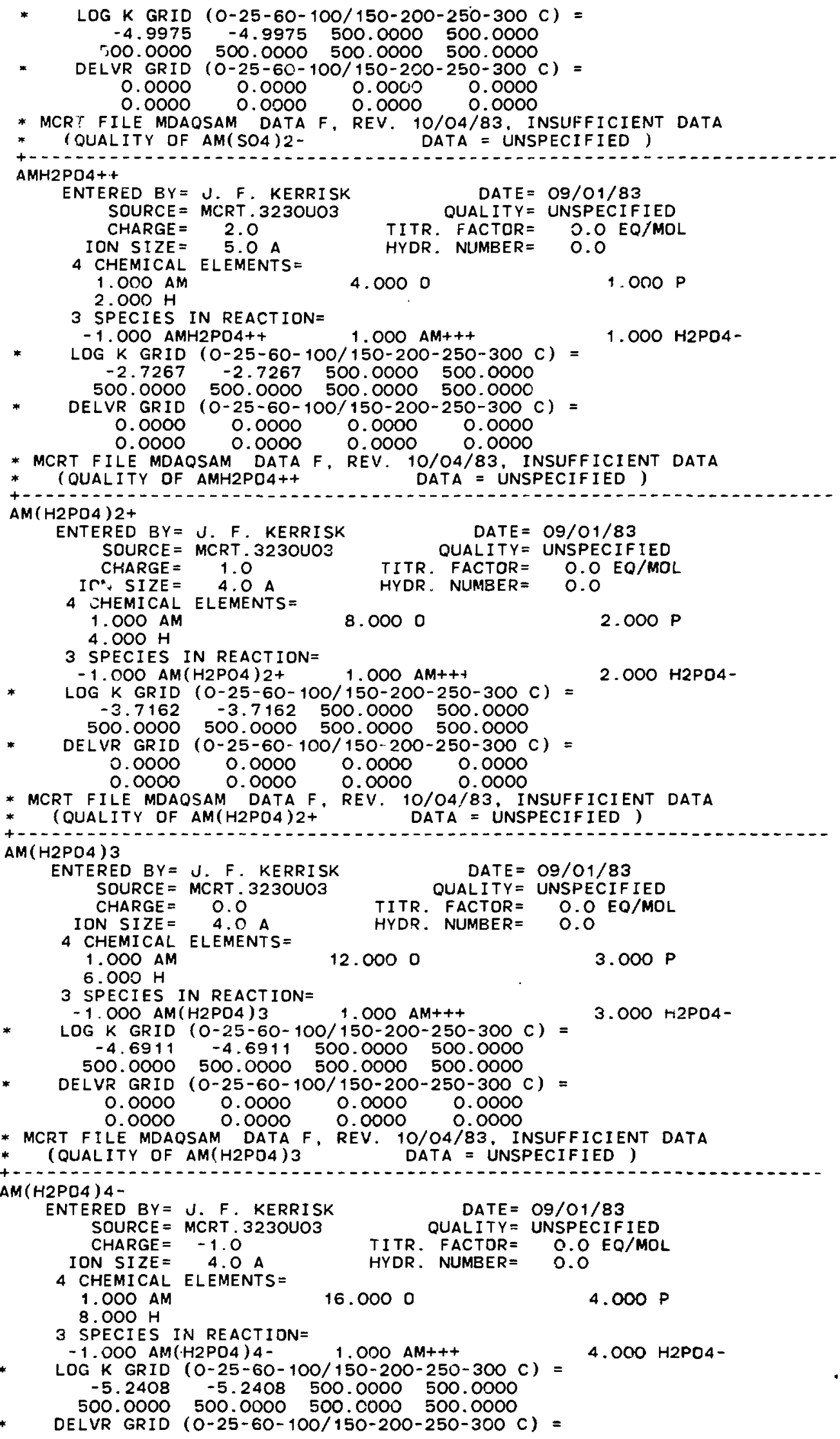




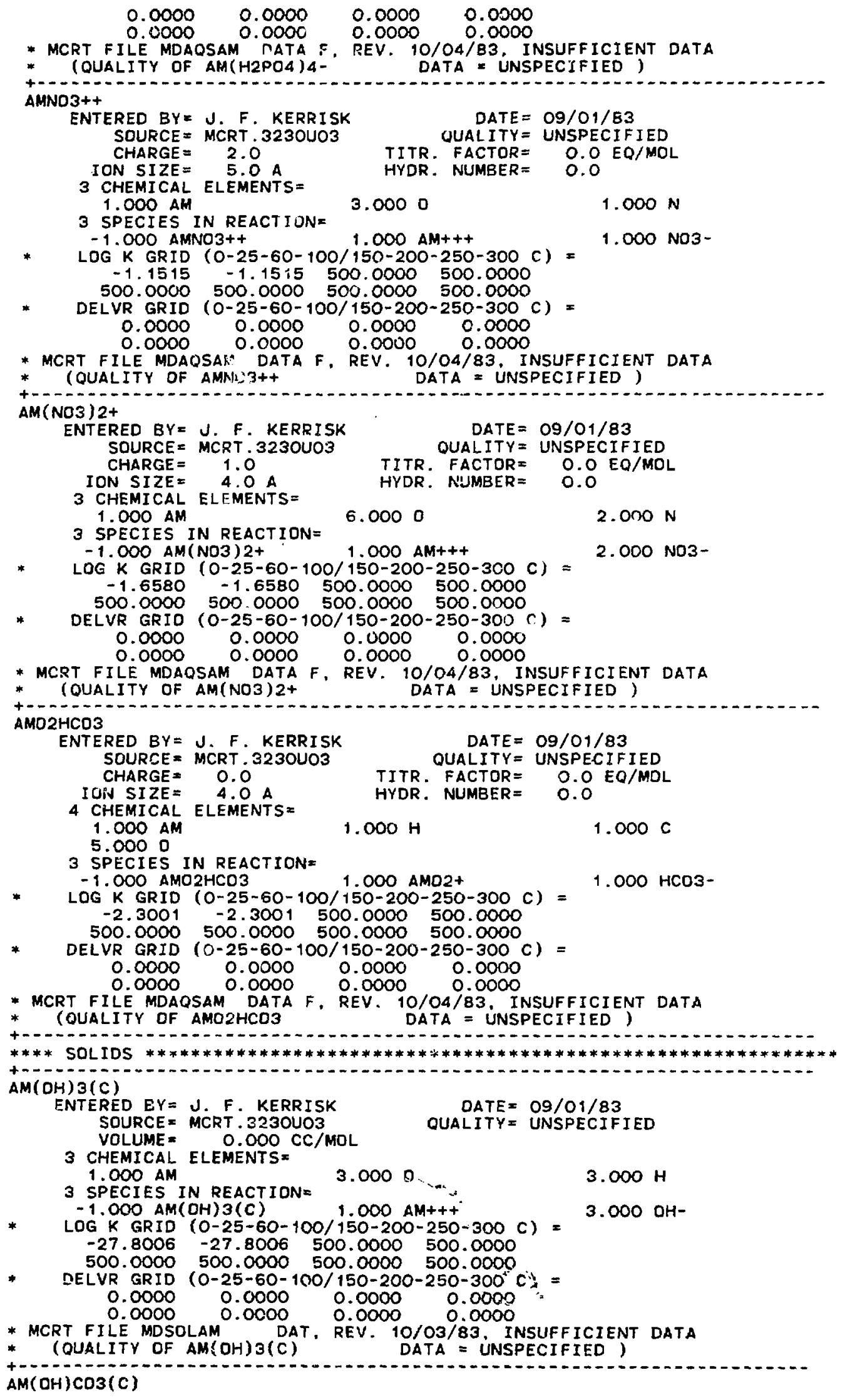




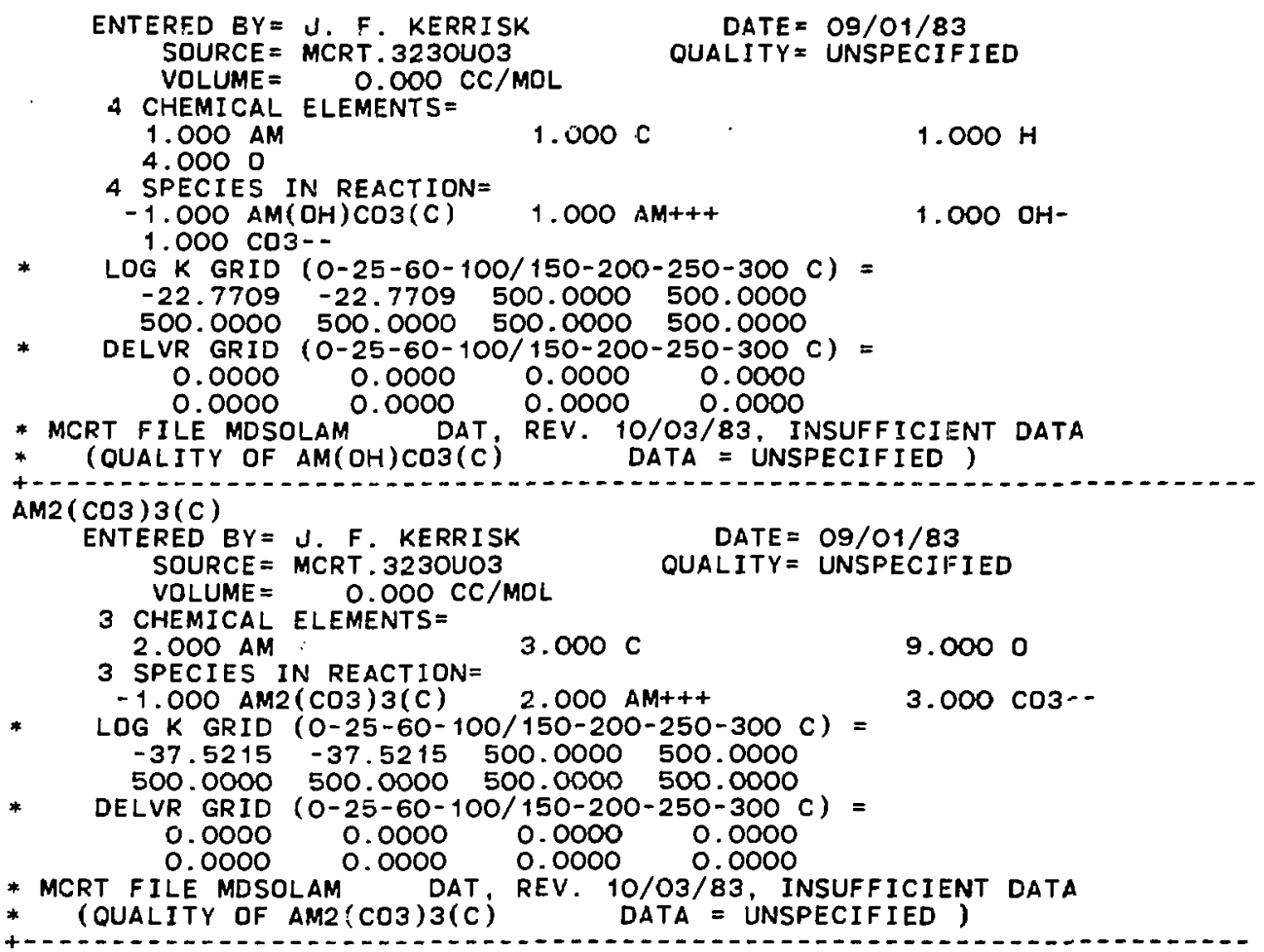

